Article

\title{
Fetal Tissue-Derived Mast Cells (MC) as Experimental Surrogate for In Vivo Connective Tissue MC
}

\author{
Caterina Iuliano ${ }^{1}$, Magdalena Absmaier-Kijak ${ }^{1}$, Tobias Sinnberg ${ }^{2}{ }^{\mathbb{D}}$, Nils Hoffard ${ }^{1}$, Miriam Hils ${ }^{1}$, \\ Martin Köberle ${ }^{1}$ (D), Florian Wölbing ${ }^{1}$, Ekaterina Shumilina ${ }^{3}$, Nicole Heise ${ }^{3}$, Birgit Fehrenbacher ${ }^{2}$ (D), \\ Martin Schaller ${ }^{2}$, Florian Lang ${ }^{3}$, Susanne Kaesler ${ }^{1, *}$ and Tilo Biedermann ${ }^{1, *}$ (D)
}

1 Department of Dermatology and Allergology, School of Medicine, Technical University Munich, Biedersteiner Str. 29, 80802 Munich, Germany; caterina.iuliano@tum.de (C.I.); magdalena.absmaier@tum.de (M.A.-K.); nils.hoffard@tum.de (N.H.); miriam.hils@tum.de (M.H.); martin.koeberle@tum.de (M.K.); florian.woelbing@tum.de (F.W.)

2 Department of Dermatology, University of Tübingen, 72076 Tübingen, Germany; tobias.sinnberg@med.uni-tuebingen.de (T.S.); birgit.fehrenbacher@med.uni-tuebingen.de (B.F.); martin.schaller@med.uni-tuebingen.de (M.S.)

3 Department of Physiology, University of Tübingen, 72076 Tübingen, Germany; ekaterina.shumilina@uni-tuebingen.de (E.S.); nicole.heise@freenet.de (N.H.); florian.lang@med.uni-tuebingen.de (F.L.)

* Correspondence: susanne.kaesler@tum.de (S.K.); tilo.biedermann@tum.de (T.B.); Tel.: +49-89-4141-3170 (S.K. \& T.B.); Fax: 49-89-4141-3171 (S.K. \& T.B.)

\section{check for}

Citation: Iuliano, C.; Absmaier-Kijak, M.; Sinnberg, T.; Hoffard, N.; Hils, M.; Köberle, M.; Wölbing, F.; Shumilina, E.; Heise, N.; Fehrenbacher, B.; et al. Fetal Tissue-Derived Mast Cells (MC) as Experimental Surrogate for In Vivo Connective Tissue MC. Cells 2022, 11, 928. https://doi.org/10.3390/ cells11060928

Academic Editor: Yoshimichi Okayama

Received: 31 January 2022

Accepted: 4 March 2022

Published: 8 March 2022

Publisher's Note: MDPI stays neutra with regard to jurisdictional claims in published maps and institutional affiliations.

Copyright: (C) 2022 by the authors. Licensee MDPI, Basel, Switzerland. This article is an open access article distributed under the terms and conditions of the Creative Commons Attribution (CC BY) license (https:// creativecommons.org/licenses/by/ $4.0 /)$.

\begin{abstract}
Bone-marrow-derived mast cells are matured from bone marrow cells in medium containing $20 \%$ fetal calf serum (FCS), interleukin (IL)-3 and stem-cell factor (SCF) and are used as in vitro models to study mast cells (MC) and their role in health and disease. In vivo, however, BM-derived hematopoietic stem cells account for only a fraction of $\mathrm{MC}$; the majority of $\mathrm{MC}$ in vivo are and remain tissue resident. In this study we established a side-by-side culture with BMMC, fetal skin MC (FSMC) or fetal liver MC (FLMC) for comparative studies to identify the best surrogates for mature connective tissue MC (CTMC). All three MC types showed comparable morphology by histology and $\mathrm{MC}$ phenotype by flow cytometry. Heterogeneity was detected in the transcriptome with the most differentially expressed genes in FSMC compared to BMMC being Hdc and Tpsb2. Expression of ST2 was highly expressed in BMMC and FSMC and reduced in FLMC, diminishing their secretion of type 2 cytokines. Higher granule content, stronger response to FceRI activation and significantly higher release of histamine from FSMC compared to FLMC and BMMC indicated differences in MC development in vitro dependent on the tissue of origin. Thus, tissues of origin imprint MC precursor cells to acquire distinct phenotypes and signatures despite identical culture conditions. Fetal-derived MC resemble mature CTMC, with FSMC being the most developed.
\end{abstract}

Keywords: mast cell; in vitro model; transcriptome; RNA sequencing; proteases; IgE

\section{Introduction}

Mast cells (MC) are tissue-resident immune cells that play a crucial role in different types of immune responses [1]. MC arise from two distinct waves of migration, originating from both erythromyeloid progenitors from the extraembryonic yolk sac, as well as from hematopoietic stem cells [2]. Of note, postnatally in vivo, bone-marrow-derived hematopoietic stem cells account for only a fraction of $\mathrm{MC}$ in the body and mainly replenish the mucosal MC population [3]. Contrary to the classic tree-like model describing hematopoiesis, single-cell RNA sequencing studies suggest that hematopoietic stem cells and progenitor cells differentiate along trajectories [4]. These studies postulate that the MC developmental route is positioned adjacent to the erythrocyte and basophil trajectories and a common $\mathrm{MC}$ /basophil progenitor [5]. MC progenitors (MCP) migrate into target 
tissues during their maturation, i.e., the intestine, skin, or serosal cavity, by extravasating from the bloodstream under basal conditions dependent on trafficking molecules CXCR2 and $B 7$ integrin and chemoattractant gradients [6,7]. Their preferential localization in the host-environmental interface allows MC to act as sentinels for tissue damage and pathogen invasion [8]. The process of becoming mature MC following tissue infiltration as progenitor cells is controlled by the microenvironment of the tissue providing stimuli such as IL-3, that lead to maturation of MC [9].

Research on MC over decades has focused on the crucial role of MC in allergic diseases such as allergic asthma and delayed-type hypersensitivity [10,11]. More recently, it has become apparent that MC play a crucial role as effector cells in innate and other adaptive immune responses [12,13]). MC express several stimulatory and inhibitory surface receptors, allowing them to respond to external stimuli by finely tuned immune responses [14]. Among the activating receptors of MC are the high-affinity IgE receptor FceRI, the Masrelated G protein-coupled receptor X2 (MRGPRX2), the alarmin IL-33 receptor ST2/IL33R and pattern recognition receptors (PRRs) sensing also danger signals, such as Toll-like receptors (TLRs). While mediators such as histamine and tryptase are stored preformed in granula and released upon degranulation, cytokines, chemokines, and growth factors are synthesized upon stimulation and released de novo [15].

In vivo models using constitutive or inducible MC-deficient mice have been very important and have helped gather compelling evidence for the relevance of $\mathrm{MC}$ in different physiological and pathological processes [12]. However, to study and fully understand MC specific functions on a cellular level, in vitro experiments are also necessary, creating a need for appropriate surrogates and models both of human and mouse origin. However, since MC mature within tissues under the direct influence of the local tissue microenvironment, it is crucial to define MC surrogates for in vitro studies more closely. Regarding mouse MC, BMMC are a helpful model for MC studies and frequently used, however, BMMC phenotypically and functionally differ from tissue-resident MC populations [16]. To be able to conduct in vitro studies, a method is needed that provides MC in sufficient quantity. Using tissue-resident $\mathrm{MC}$ from mature origins such as adult skin neither provides sufficient yield for in vitro analysis nor do mature MC proliferate in vitro, whereby MC from mature origin do not act as potential surrogates.

Over the past decades, various methods have been developed to promote the differentiation and maturation of MC from precursor cells and to effectively extract them from tissues [17]. However, transcriptional analysis of MC originating from different tissues has demonstrated considerably greater heterogeneity across tissues than previously appreciated [18]. Due to this increasing evidence of MC heterogeneity and tissue specificity, it is crucial to address this issue in experimental setups and to also choose the appropriate MC surrogate for in vitro studies. To this end, a better characterization and side-by-side comparison of MC surrogates could be a prerequisite for the most adequate selection. In the present study, we describe the generation of MC originating from bone-marrow (BMMC), fetal liver (FLMC), and fetal skin (FSMC) and compare these three MC types regarding phenotypic markers, proliferation, and mediator content as well as response to mitotic activation, IgE-crosslinking of the FceRI receptor and innate stimulation. While histology and flow cytometric analyses revealed nearly identical results following standardized culture conditions, our data showed differences between the three MC types at the gene expression level and in regard to mediator release. Primarily due to high histamine content and strong reactivity towards type 2 immune signals, fetal-skin derived MC were identified as the preferred choice for analyses aiming to decipher the role of $\mathrm{MC}$ in allergic inflammation and atopic diseases, especially of the skin.

\section{Materials and Methods}

\subsection{Animals}

C57BL/6N mice were purchased from Charles River (Sulzfeld, Germany). Animals were kept under specific pathogen-free conditions in accordance with the guidelines of 
the Federation of European Laboratory Science Association and the German Animal Welfare Act.

\subsection{In Vitro Generation of Mast Cells}

Generation of BMMC: 6- to 8-week-old C57BL6N mice were euthanized by isoflurane and cervical dislocation. Bone marrow cells were then prepared from femur and tibia and cultured in RPMI 1640 medium (Biochrom, Berlin, Germany) with 20\% FCS (CH 30160.03 Hyclone Perbio), 1\% X63Ag8-653mIL-3-conditioned medium corresponding to $10 \mathrm{ng}$ IL-3/mL, 1\% CHO-murine stem cell factor conditioned media corresponding to $50 \mathrm{ng}$ $\mathrm{mSCF} / \mathrm{mL}$ ), $50 \mathrm{U} / \mathrm{mL}$ penicillin/streptomycin (Biochrom, Berlin, Germany) and $20 \mu \mathrm{M}$ $\beta$-mercaptoethanol (Merck, Darmstadt, Germany) (henceforth referred to as MC-medium), for 21 days at $37{ }^{\circ} \mathrm{C}$ and $5 \% \mathrm{CO}_{2}$. Conditioned media were obtained from cell culture supernatants of the above-mentioned cell lines. Concentration estimation of IL-3 and SCF was performed using proliferation assays with FDCP-1 cells (IL-3 dependent) and TF-1 (SCF-dependent).

Generation of FSMC and FLMC: Fetuses were retrieved from C57Bl/6N mice 16 days post gestation period and decapitated. Back skin was prepared from the fetuses, digested in $0.25 \%$ Trypsin-EDTA solution (Gibco Thermo Fisher Scientific, Munich, Germany) and passed through cell strainers (Cambrex, NJ, USA). The livers were removed from fetuses and single cell suspensions were prepared from them. Erythrocytes were lysed with ACK lysis buffer (BioWhittaker, Lonza, Swiss) and cell suspension was cultured for 21 days in complete mast-cell medium as described before. All cultured media were tested regularly for mycoplasma and no contamination was detected.

\subsection{Flow Cytometry for Mast Cell Surface Markers}

The surface expressions of Fc\&RI, CD117 (c-kit), ST2, $\beta$-Integrin and CD49b were analyzed by flow cytometry. Briefly, $1 \times 10^{6}$ mast cells were washed with PBS and incubated with an anti-CD16/CD32 mAb (clone 32, Biolegend, London, UK) for Fc receptor blocking. The following primary, fluorochrome-coupled antibodies were used for analysis: antiCD45.2 (clone 104, Biolegend), anti-FceRI (clone MAR-1, Biolegend), anti-CD117 (clone 2B8, Biolegend), anti-ST2 (clone DIH4, Biolegend), anti-integrin-B7 (clone FIB27, Biolegend) and anti-CD49b (clone DX5, Biolegend) and Live/Dead fixable aqua dead cell stain (Invitrogen Thermo Fischer, Munich, Germany). Cells were determined fully matured if $>90 \%$ were $\mathrm{Fc} \varepsilon \mathrm{RI}^{+} \mathrm{CD} 117^{+}$and only then further studies were conducted.

\subsection{Histology}

Histological staining was performed after cells were determined matured as determined by flow cytometry. A total of $1 \times 10^{4}$ cells were cytocentrifuged onto a glass slide and air dried. For Alcian Blue staining, slides were stained with 1.0\% alcian blue (SigmaAldrich/Merck, Darmstadt, Germany) at pH 2.5 in 1\% acetic acid, followed by staining for 15 min with $0.1 \%$ safranin $\mathrm{O}$ at $22{ }^{\circ} \mathrm{C}$ (Sigma-Aldrich/Merck, Darmstadt, Germany). For Giemsa staining, slides were stained in 5\% Giemsa (Sigma-Aldrich/Merck) for $20 \mathrm{~min}$ at $22{ }^{\circ} \mathrm{C}$. Slides were examined under a light microscope (DM3000, Leica Biosystems; Nußloch, Germany).

\subsection{Transmission Electron Microscropy}

Cells were fixed with Karnovsky's fixative for $24 \mathrm{~h}$ at $4{ }^{\circ} \mathrm{C}$. Post-fixation was based on $1.0 \%$ osmium tetroxide containing $1.5 \% \mathrm{~K}$-ferrocyanide in $0.1 \mathrm{M}$ cacodylate buffer for $2 \mathrm{~h}$. After following standard methods, blocks were embedded in glycide ether and cut using an ultramicrotome (Ultracut, Reichert, Vienna, Austria). Semithin sections were stained with Toluidinblue (1\% Morphisto, Frankfurt am Main, Germany) and examined under a Nikon eclipse 80i microscope (Nikon Europe BV, Amsterdam, The Netherlands). Ultra-thin sections $(30 \mathrm{~nm})$ were mounted on copper grids and analyzed using a Zeiss 
LIBRA 120 transmission electron microscope (Carl Zeiss, Oberkochen, Germany) operating at $120 \mathrm{kV}$.

\subsection{Proliferation, Histamine Release and Hexosaminidase Content}

For proliferation experiments, MC were cultured with $0.25 \mu \mathrm{Ci}$ of $\left[{ }^{3} \mathrm{H}\right]$ Thymidine (Amersham, GE Healthcare, Freiburg, Germany) for $14 \mathrm{~h}$. The cells were harvested using a FilterMate Harvester (PerkinElmer LAS, Rodgau, Germany) and incorporation analyzed in a MicrobetaTriLux Luminescence Counter (PerkinElmer LAS, Rodgau, Germany). Incorporated radioactivity is expressed as counts per minute.

For IgE sensitization, $1 \times 10^{5}$ cells were pre-incubated with $1 \mu \mathrm{g} / \mathrm{mL}$ anti-DNP IgE (Sigma-Aldrich/Merck) for $24 \mathrm{~h}$ at $37^{\circ} \mathrm{C}$. For cross-binding and activation of the receptor, the cells were then stimulated with $40 \mathrm{ng} / \mathrm{mL}$ DNP-HSA (Sigma-Aldrich/Merck) for $30 \mathrm{~min}$. Control stimulation was performed with phorbol-12-Myristat-13-Acetate (PMA) (Sigma, Taufkirchen, Germany) and ionomycin (Sigma-Aldrich/Merck) or 0.1\% TritoxX100 (SigmaAldrich/Merck) for complete lysis at $37^{\circ} \mathrm{C}$. For histamine ELISA, cells were cultured in MC-medium, while for $B$-hexosaminidase assay, cells were transferred in Tyrodes Buffer (Sigma). Histamine release was analyzed using Histamine ELISA (LSBio, Seattle, WA, USA). For $ß$-hexosaminidase release, $50 \mu \mathrm{L}$ of supernatant was incubated with $50 \mu \mathrm{L}$ of $\mathrm{p}$ nitrophenyl-N-acetyl- $\beta$-D-glucosaminide (Sigma-Aldrich/Merck) for $2 \mathrm{~h}$ at $37^{\circ} \mathrm{C}$. Reaction was stopped with Tris-HCl buffer (Sigma-Aldrich/Merck) and colorimetric measured at $405 \mathrm{~nm}$ using an ELISA Reader Multiskan EX (Thermo Fisher Scientific, Munich, Germany).

\subsection{Cytokine Measurements}

A total of $1 \times 10^{6} \mathrm{MC}$ were cultured in 24-well plates and stimulated with either 100 ng/mL Pam2Cys (EMC microcollections, Tübingen, Germany), 100 ng/mL Pam3Cys (EMC microcollections, Tübingen, Germany), $10 \mathrm{ng} / \mathrm{mL}$ LPS from s.minnesota (Alexis, Lausen, Swiss), 0.5 M CpG OD 1668 (Eurofins MWC Operon, Ebersberg, Germany), 10 ng/mL PolyIC (Invivogen, Toulouse, France), $10 \mathrm{ng} / \mathrm{mL}$ imiquimod (Invivogen), $10 \mathrm{ng} / \mathrm{mL}$ IL-33 (PeproTech, Hamburg, Germany) ionomycin (Sigma-Aldrich/Merck) or phorbol-12-myristat13-acetate (PMA) (Sigma-Aldrich/Merck) for $24 \mathrm{~h}$ at $37^{\circ} \mathrm{C}$ in MC-medium. Supernatants were quantified by enzyme-linked immunosorbent assay for IL-10 (R\&D Systems, Minneapolis, MN, USA, detection limit 15.6-1000 pg/mL), IL-6 (R\&D Systems, Minneapolis, MN, USA, detection limit 15.6-1000 pg/mL), TNF-a (R\&D Systems, detection limit 10.9-700 pg/mL), LegendPlex Mouse Inflammation panel (BioLegend, San Diego, CA, USA) and LegendPlex Mouse Th Cytokine panel (Biolegend).

\subsection{Patch-Clamp Analysis}

Patch-clamp experiments were performed at room temperature in voltage-clamp, fast whole-cell mode. MC were continuously superfused by a flow system inserted into the dish. The bath was grounded via a bridge filled with $\mathrm{NaCl}$ Ringer solution. Borosilicate glass pipettes (2- to 4-megaohm (Mohm) tip resistance; GC 150 TF-10; Clark Medical Instruments) manufactured by a microprocessor-driven DMZ puller (Zeitz) were used in combination with a MS314 electrical micromanipulator (MW; Märzhäuser). The currents were recorded by an EPC-9 amplifier (HEKA) using Pulse software (HEKA) and an ITC-16 Interface (Instrutech). Whole-cell currents were determined as 10 successive 200-ms square pulses from a $-35 \mathrm{mV}$ holding potential to potentials between $-115 \mathrm{mV}$ and $+65 \mathrm{mV}$. The currents were recorded with an acquisition frequency of 10 and $3 \mathrm{kHz}$ low-pass filtered. Where indicated, the Ag DNP-HSA (50 ng/mL), endothelin-1 (100 nM), the channel blocker TRAM-34 (300 nM; Sigma, Taufkirchen, Germany), and/or the $\mathrm{Ca}^{2+}$ ionophore ionomycin (1 $\mu \mathrm{M}$; Sigma) were added to the bath solution.

The offset potentials between both electrodes were zeroed before sealing. The original whole-cell current traces are depicted without further filtering and currents of the individual voltage square pulses are superimposed. The applied voltages refer to the cytoplasmic face of the membrane with respect to the extracellular space. The inward currents, defined 
as flow of positive charge from the extracellular to the cytoplasmic membrane face, are negative currents and are depicted as downward deflections of the original current traces.

\subsection{Intracellular Calcium Measurement}

Intracellular $\mathrm{Ca}^{2+}$ measurements were performed using fura-2AM. Briefly, MC were loaded with fura-2AM ( $2 \mu \mathrm{M}$; Molecular Probes) for $20 \mathrm{~min}$ at $37^{\circ} \mathrm{C}$. The cells were continuously superfused to remove leaked-out extracellular fura-2. Fluorescence measurements were conducted with an inverted phase-contrast microscope (Axiovert 100; Zeiss, Oberkochen, Germany). Cells were excited alternatively at 340 and $380 \mathrm{~nm}$ and the light was deflected by a dichroic mirror into either the objective (Fluar $\times 40 / 1.30$ oil; Zeiss) or a camera (Proxitronic) mounted on the microscope. Emitted fluorescence intensity was recorded at $510 \mathrm{~nm}$ and data acquisition was performed by using Metafluor computer software (Universal Imaging). To determine the fluorescence intensity in single cells, the regions of interest were determined as circuits closely surrounding individual cells. After a control period to wash the cells and remove any non-gathered dye, intracellular $\mathrm{Ca}^{2+}$ was measured before and following addition of DNP-HSA $(50 \mathrm{ng} / \mathrm{mL})$ to IgE-sensitized MC, in the absence or presence of extracellular $\mathrm{Ca}^{2+}$. As a measure of the increase of cytosolic $\mathrm{Ca}^{2+}$, the slope and peak of the changes in the $340 / 380 \mathrm{~nm}$ ratio were calculated for each experiment. To reach nominally $\mathrm{Ca}^{2+}$-free conditions, experiments were performed using $\mathrm{Ca}^{2+}$-free Ringer solution containing (in mmol/L): $125 \mathrm{NaCl}, 5 \mathrm{KCl}, 1.2 \mathrm{MgSO}_{4}, 2 \mathrm{Na}_{2} \mathrm{HPO}_{4}$, 32.2 Hepes, 0.5 EGTA, 5 glucose (pH 7.4). For intracellular calibration purposes, ionomycin $(10 \mu \mathrm{M})$ was applied at the end of each experiment.

\subsection{Analysis of Gene Expression}

Total RNA was extracted from MC using the PeqGold Total RNA Kit (PeqLab, VWR, Darmstadt, Germany). A total of $1 \mu \mathrm{g}$ of RNA was digested with the DNase I Kit according to the manufactures protocol (DNase I AMP Grade, Thermo Fischer) and cDNA synthesis performed using the iScript cDNA Synthesis Kit (Bio-Rad Laboratories, Munich, Germany) with $10 \mathrm{mM}$ dNTPs, oligo(dt)-18 primer and reverse transcriptase according to the manufacturer's instructions. Quantitative real-time PCR was carried out on a StepOne ${ }^{\mathrm{TM}}$ Real-Time PCR System (LifeTechnologies GmbH, Darmstadt, Germany). Values were normalized to the housekeeping gene $\beta$-actin. A list of used primers is provided in the Supplementary Materials.

\subsection{RNA Sequencing}

Total RNA was isolated from MC after four weeks of culture with the PeqGold Total RNA Isolation Kit (VWR, Radnor, PA, USA). Quality and integrity of total RNA was controlled using NanoDrop 2000 spectrophotometer (Thermo Fisher Scientific) and 2100 Bioanalyzer (Agilent Technologies). To prepare a library of barcoded cDNA for bulk 30sequencing, poly(A)-mRNA was reverse transcribed with Maxima RT polymerase (Thermo Fisher Scientific, Munich, Germany) using oligo-dT primer containing barcodes, unique molecular identifiers (UMIs) and an adaptor. The $5^{\prime}$ ends of the cDNAs were extended by a template switch oligo (TSO) and full-length cDNA was amplified with primers binding to the TSO-site and the adaptor. NEB UltraII FS kit was used to fragment cDNA. After end repair and A-tailing, a TruSeq adapter was ligated and $3^{\prime}$-endfragments were finally amplified using primers with Illumina P5 and P7 overhangs. The library was sequenced on a NextSeq 500 (Illumina).

High-throughput gene expression data analysis was carried out using the $\mathrm{R}$ environment for statistical computing. Briefly, genes were normalized using DeSeq2 and a principal component analysis was performed. Next, pairwise comparisons were performed using edgeR and gene set enrichment analysis (GSEA). Additional gene set analysis was performed using the Degust webtool. 


\subsection{Statistics}

If not otherwise stated, data are presented as the mean \pm SEM. Statistical analysis of data was performed with unpaired Student's $t$ test (2 tailed) or with 2-way repeatedmeasures ANOVA and Tukey's multiple-comparisons test. Analysis was performed with GraphPad Prism software (GraphPad, San Diego, CA, USA). $p$ values less than 0.05 were considered statistically significant and are marked as follows: ${ }^{*} p<0.05 ;{ }^{* *} p<0.001$; *** $p<0.005$.

\section{Results}

\subsection{Phenotypes following Cultures of Bone Marrow Cells and Fetal Tissues}

To generate MC in vitro, we isolated cells from bone marrow of adult C57BL/6N mice or fetal liver and fetal skin from C57BL/6N d16 embryos. We cultivated them in medium containing murine interleukin (mIL-)-3 and murine stem cell factor (mSCF) (Figure S1A). The SCF receptor, c-kit (CD117), is one of the most critical receptors on mature $\mathrm{MC}$, as a reduction in c-kit signaling leads to MC deficiency [6]. In line with this, our experiments demonstrated a downregulation of c-kit as early as $24 \mathrm{~h}$ after deprivation of SCF from culture medium (Figure S1B,C). For comparability of the following analyses, culture conditions were kept constant for MC cultures from the three tissues investigated, i.e., bone marrow, fetal liver, and fetal skin, using medium supplemented with $20 \%$ FCS, $10 \mathrm{ng} / \mathrm{mL}$ IL-3 and $50 \mathrm{ng} / \mathrm{mL}$ SCF (Figure S1D).

We first determined whether this in vitro culture was capable of generating MC from the different tissues. Flow cytometry analysis showed a difference in granularity, with FSMC showing the highest granularity (Figure S2A). We classified MC from our cultures as fully developed MC by flow cytometry when $>90 \%$ of viable cells were $\mathrm{CD} 45.2^{+} \mathrm{CD} 117^{+} \mathrm{Fc} \varepsilon \mathrm{RI}^{+}$(Figure 1A). Surface expression of integrin $\beta 7$ on fetal MC precursors (MCP) is essential for the migration to the developing organ [19]. Committed $\mathrm{MCP}$ lose $\beta 7$ integrin upon becoming MC [6]. Consistent with MC, the homing receptor $\beta 7$ integrin declined in the cells from all three tissue types from week three of culture onwards, and was fully downregulated by week 5 (Figure S2B). Fetal skin-derived MC were previously characterized as $\mathrm{CD} 45^{+} \mathrm{CD} 49 \mathrm{~b}^{+} \mathrm{CD} 117^{+} \mathrm{Fc \varepsilon RI}{ }^{+}$, thereby showing a strong similarity to mature connective tissue (CT) MC [20,21]. Indeed, we found CD49b to be only expressed on fetal tissue-derived MC, suggesting that fetal-derived MC closely resemble mature cutaneous MC (Figure S2C) [20,21]. Both BMMC and FSMC were fully developed after four weeks of culture, while FLMC required a longer time (see Table 1).

MC are mononuclear cells identified by metachromatic staining of their secretory granules. A well-established method for detecting secretory granules is toluidine blue staining, which stains $\mathrm{MC}$ in dark violet compared to the orthochromatic staining of other cell types [22]. Toluidine blue binds heparin, which is more abundant in mature connective tissue MC and correlates with the degree of differentiation towards mature MC [23]. The dark violet staining identified the generated cells of all three cultures as MC with more granules visible in FSMC compared to BMMC (Figure 1B, upper panel). This is confirmed by Giemsa staining, another method to identify MC by staining the cytoplasm of MC with dark blue color, while the granules are red-stained [24]. Giemsa staining of the MC confirmed the higher granularity of FSMC compared to BMMC (Figure 1B, middle panel). The combined staining of MC with Alcian blue and Safranin-O allows simultaneous differentiation of mucosal-like MC (MMC) and connective-tissue-like MC (CTMC) [25]. FSMC granules showed a more intense red coloration than BMMC, indicating a higher heparin content (Figure 1B, lower panel). When examined by electron microscopy, more numerous granules were seen in FSMC with the granules being larger and more homogeneous (representative pictures in Figure 1C). A cross section of the cell was analyzed and the number of granules per section quantified, showing that FSMC have the highest granule density (Figure 1D). In accordance with the lower yield, the lowest proliferation rate was found for FSMC (Figure 1E), indicating that MC maturity inversely correlated with proliferative capacity, as has also been shown for other cell types such as beta-cells [26] or cardiomyocytes [27]. 
Thus, all three tissues, bone marrow, fetal liver, and fetal skin, give rise to $\mathrm{MC}$ as seen in our side-by-side cultures, but histological staining and morphological properties indicate that FSMC are closest to tissue-derived mature MC whereas BMMC represent $\mathrm{MC}$ that are least developed/matured.

a
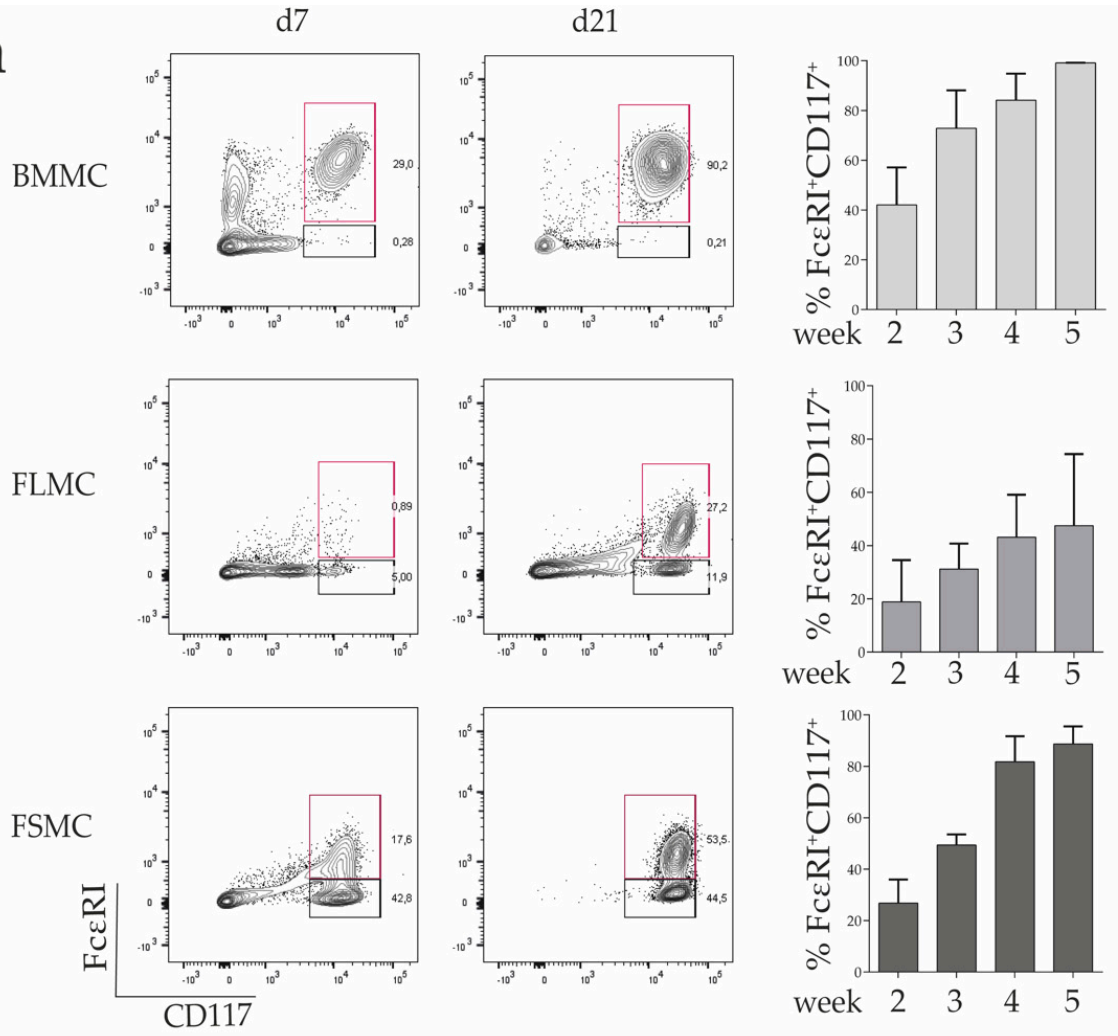

b

Toluidin Blue

BMMC

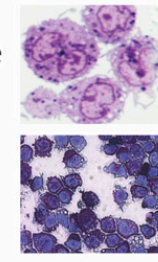

Giemsa

Alcian Blue/ Safranin O
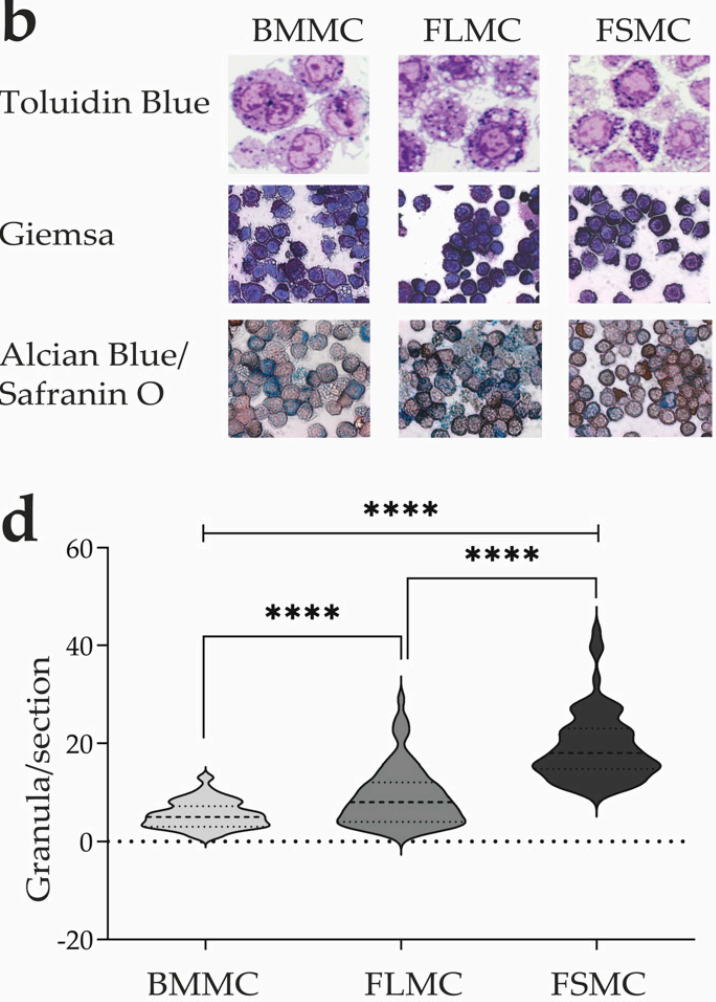

C


FSMC

e

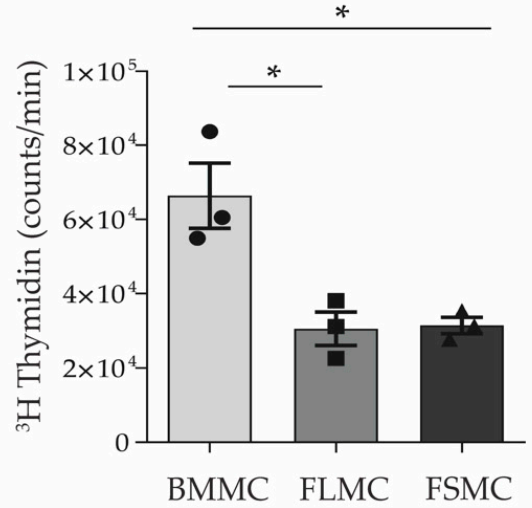

Figure 1. Generation and characterization of MC. (a) MC determined by surface markers using flow 
cytometry. Cells were cultured in medium with SCF and IL-3 and flow cytometry performed weakly. Mature $\mathrm{MC}$ were classified as $\mathrm{LD}^{-} \mathrm{CD} 45.2^{+} \mathrm{Fc} \varepsilon \mathrm{RI}^{+} \mathrm{CD} 117^{+}$cells. Bar graphs represent quantification of maturation from week 2 until week 5 ( $n=3$, mean with SEM). (b) Morphology of BMMC, FLMC and FSMC analyzed by histology. Semithin sections were stained with Toluidin Blue (top panel, $100 \times$ magnification), Giemsa (middle panel, $40 \times$ magnification), and Alcian Blue/Safranin O (bottom panel, $40 \times$ magnification). (c) Structural analysis of MC was conducted by electron microscopy. Representative images with red arrows representing areas with granules (scalebar $1 \mu \mathrm{M})$, (d) quantification of granules per section $(n=70)$. (e) Proliferation of MC based on the incorporation of ${ }^{3} \mathrm{H}$-thymidine. Proliferation rate determined as counts $/ \min (n=3$, mean with SEM). Unpaired $t$-test ${ }^{*} p>0.05,{ }^{* * * *} p>0.0001$.

Table 1. Yield and maturation time for MC types.

\begin{tabular}{ccc}
\hline Cell Type & Culture Time (in Weeks) & Yield \\
\hline BMMC & $4-6$ & $1 \times 10^{8} /$ tibia \\
FLMC & $6-10$ & $5 \times 10^{7} /$ embryo \\
FMSC & $4-6$ & $1 \times 10^{7} /$ embryo \\
\hline
\end{tabular}

\subsection{ST2 Expression on the Different MC and Response to IL-33 Stimulation}

MC, together with ILC2 and Tregs, are the only cell types that constitutively express ST2, the receptor for IL-33, at high levels, while all other cell types that respond to extracellular IL33 are either ST2 negative at steady-state and only induce ST2 expression upon activation [28]. Therefore, as another marker for MC, we measured the surface expression of ST2 on BMMC, FLMC and FSMC. All three MC types express ST2 on the cell surface following our MC culture, however, FLMC showed a significantly reduced MFI for ST2 compared to BMMC, suggesting reduced density of ST2 on the surface of FLMC (Figure 2A,B). IL-33, an alarmin involved in type 2 immune responses, causes the activation and proliferation of MC through interaction with ST2 [29]. Thus, MC were stimulated with $10 \mathrm{ng} / \mathrm{mL}$ IL-33 for $1 \mathrm{~h}$, cell pellets were harvested for RNA isolation and for further RT-PCR analysis. Upon stimulation with IL-33, BMMC and FSMC showed a comparably high increase in fold change for Il13, a MC-derived type 2 immune cytokine, while FLMC showed a significantly lower expression (Figure 2C). This result confirmed others e.g., by Leyva-Castillo et al., who showed IL-33-dependent upregulation of Il13 expression in skin MC [30]. To test the functional relevance of the ST2 expression further, MC were stimulated with $10 \mathrm{ng} / \mathrm{mL}$ IL-33 for $24 \mathrm{~h}$ and type 2 specific cytokines were measured in the supernatant. Correlating surface expression of ST2, both BMMC and FSMC show a strong response to ST2-dependent activation by secreting high concentrations of type 2 immune cytokines such as IL-4, IL-9, IL-13 but also of IL-17, amongst others. In FLMC, which showed the lowest surface expression of ST2, only IL-10 and IL-9 were detectable in the supernatant upon IL-33 stimulation (Figure 2D). 




C

Il13



b ST2/IL33R

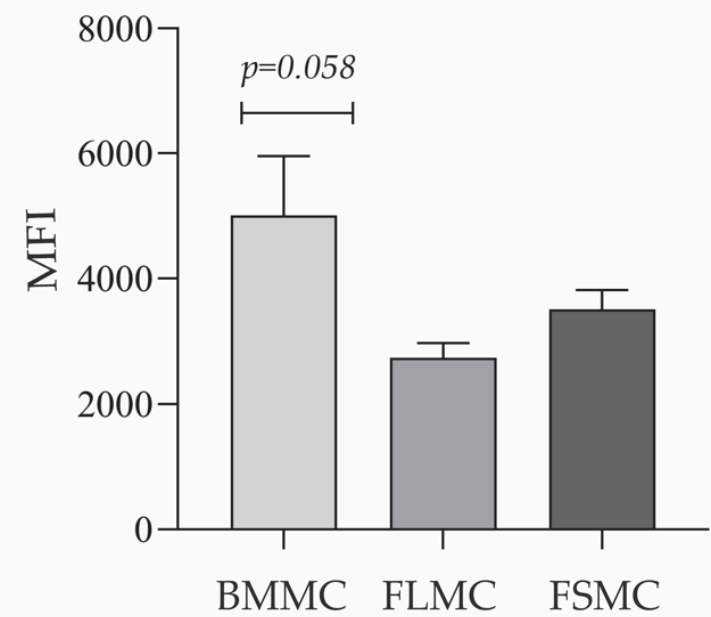

d
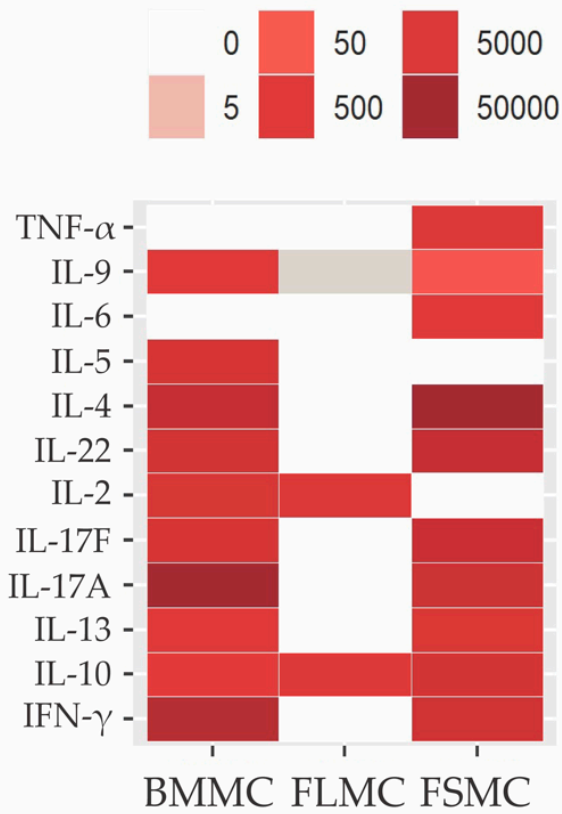

Figure 2. MC response to IL-33 stimulation. Flow cytometry analysis of surface receptor ST2 shown as (a) a representative histogram of surface expression on BMMC (light grey), FLMC (medium grey) and FSMC (dark grey) and (b) quantified as mean fluorescent intensity (MFI) ( $n=4$, mean with SEM). (c) MC were stimulated with $10 \mathrm{ng} / \mathrm{mL}$ IL-33 for $1 \mathrm{~h}$ and RNA was isolated. mRNA expression level of IL-13 was analyzed by quantitative real-time PCR. Fold change determined as $2^{-\Delta \Delta \mathrm{ct}}(n=3$, mean

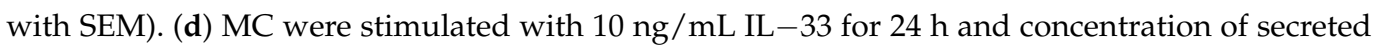
type 2 cytokines were measured in the supernatant via enzyme-linked immunosorbent assay $(n=3$, mean with SEM). Color gradient is depicted from $0-50,000 \mathrm{pg} / \mathrm{mL}$. 


\subsection{Transcriptional Profiling of MC Derived from Cultures from Different Tissues}

Differences in phenotypes, constitutive mediator production and granule contents should be associated with differentially regulated gene transcription. Thus, in the next step, we performed transcriptional profiling of the three MC types generated from the different tissues in vitro. For this purpose, RNA was isolated from $3 \times 10^{7}$ cells from the cultured BMMC, FSMC, and FLMC, all of which were $>90 \% \mathrm{CD}^{+} 17^{+} \mathrm{Fc}_{\mathrm{C}} \mathrm{RI}^{+}$based on flow cytometry. Following standard procedure, RNA sequencing was performed and transcriptome profiling analyzed using the R-tool DESeq2 and the webtool Degust (www.degust.erc.monash.edu/degust/compare; accessed 12 December 2021). Principal component analysis revealed that the three MC populations cluster separately, demonstrating that differences in phenotype, morphology and behavior as detected in our previous experiments were indeed linked to alterations in gene transcription. Interestingly, MC derived from fetal skin (FSMC), represented in orange, showed the highest degree of variance compared to the other MC types (Figure 3A). Since the classic and most used method of $\mathrm{MC}$ generation in vitro is from bone marrow, we next normalized the expression levels of transcribed genes from FLMC and FSMC against those from BMMC.

MC of both the connective tissue (CTMC) and the mucosal type (MMC) store large numbers of cytoplasmic granules that are rapidly exocytosed following activation and which contain, among others, proteases, primarily serine proteases. CTMC and MMC differ in the expression of proteases [31]. Differential mRNA expression between the three MC types showed no significant difference in expression of CTMC-associated signature genes such as the serine protease Mcpt5 (Cma1) and carboxypeptidase (CPA)3 in fetal-derived $\mathrm{MC}$ compared to BMMC, indicating that all three MC types can be classified as CTMC based on protease expression. This is further supported by RT-PCR data showing both Mcpt1 and Mcpt2, two typical mucosal type MC genes, not detectable in any of the MC types (Figure 3B). Analysis of the fetal MC types showed an increased fold change of Camp expression, which is associated with calcium-binding and IP3 signaling, in FLMC compared to BMMC (Figure 3C). Of note, fetal skin MC showed higher expression levels of mas-related G protein-coupled receptor (Mrgpr)b2 and Mrgprb1 (Figure 3D). Figure 3E depicts a heatmap of the top 20 differentially expressed genes within BMMC, FLMC and FSMC. The highest divergence in gene expression between BMMC and the fetal-derived MC show Tpsb2, the gene encoding for beta-II tryptase (Mcpt6) and Hdc, which catalyzes the biosynthesis of histamine from histidine. Both genes encode proteins characteristic for MC [32]. Both S100a8 and S100a9, which are calcium-binding proteins that regulate inflammatory processes and immune responses towards TLR4 signaling, showed lower expression in FSMC.

Dywer et al. analyzed the heterogeneity of $\mathrm{MC}$ on a transcriptional level and revealed three distinct connective tissue MC subsets with varying capacity for in situ proliferation in the absence of tissue inflammation. Based on these data, a MC-specific gene signature was extrapolated [18]. Analyzing the gene expression of the Dwyer MC-signature in our three MC types showed a differential gene expression between the fetal-derived MC and BMMC (Figure 3F). 
a

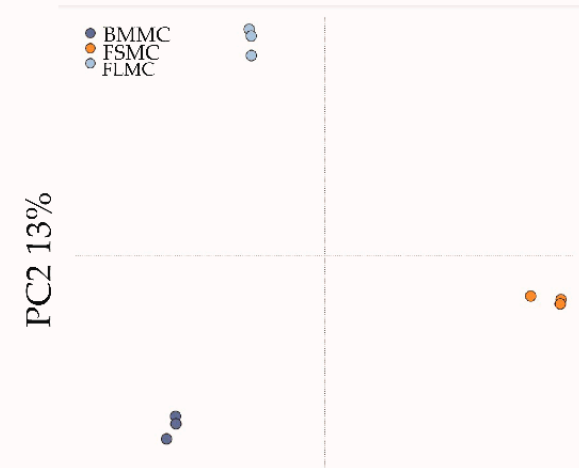

PC1 83\%

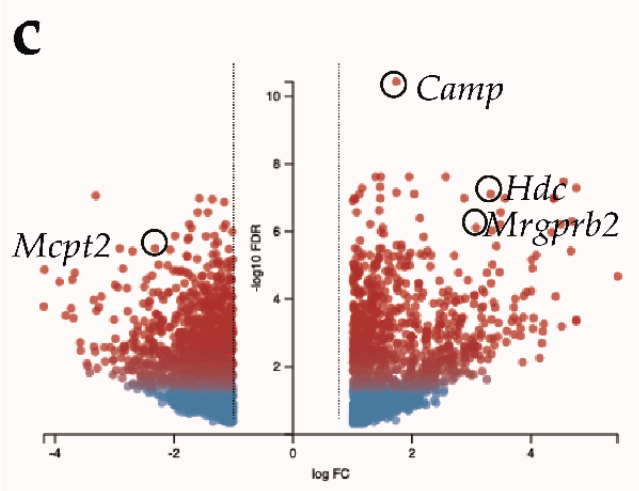

FLMC vs. BMMC

e

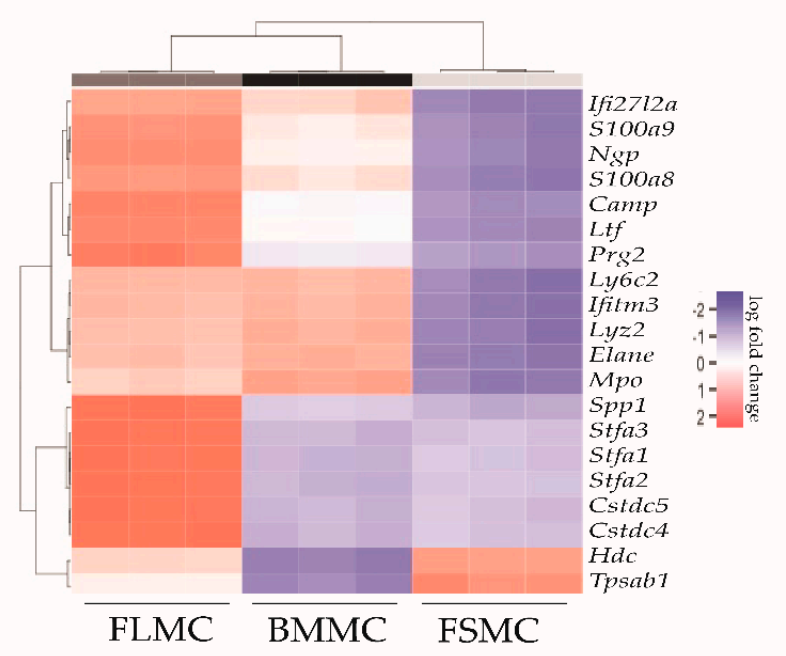

b

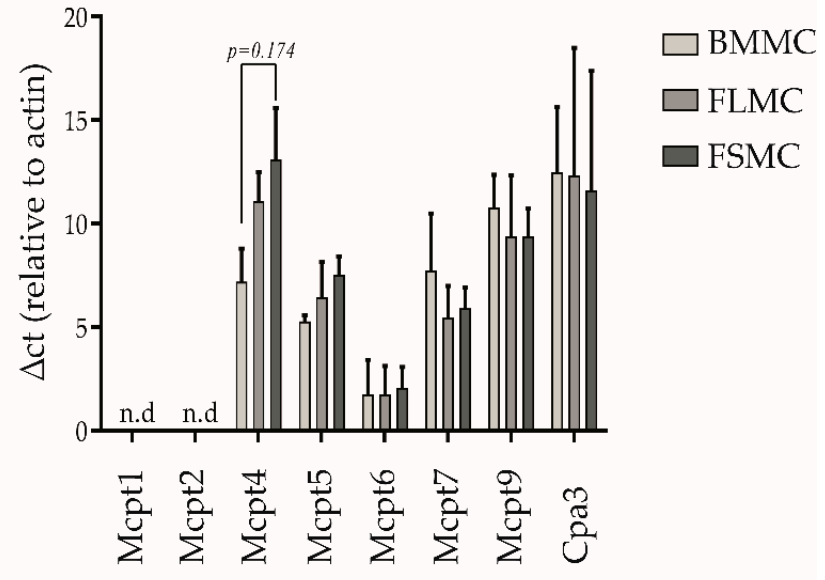

d

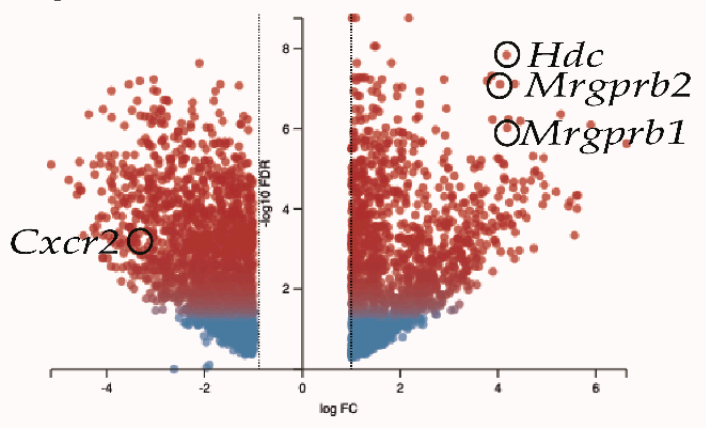

FSMC vs. BMMC

f

塄荄

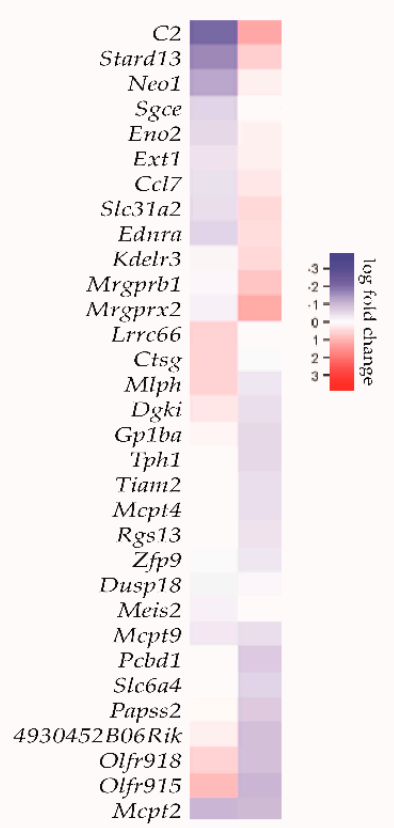

Figure 3. MC transcriptome analysis. (a) RNA sequencing of BMMC (dark blue), FLMC (light blue) 
and FSMC (orange) was performed. Principal component analysis showed variance among the MC types $(n=3)$. (b) MC protease mRNA expression analyzed by quantitative real-time PCR. $\Delta$ ct values relative to housekeeping gene $\beta$-actin $(n=3$, mean with SEM). (c,d) Volcano plot of differentially expressed genes between the groups (c) FLMC vs. BMMC and (d) FSMC vs. BMMC analyzed with the webtool Degust $(n=3, \mathrm{FDR} \leq 0.01$, abslogFc $>1)$. (e) Heatmap showing the top 20 DEG between BMMC (black), FLMC (dark grey) and FSMC (light grey). Upregulated genes are shown in red and downregulated genes in blue $(n=3)$. (f) Differential expression of genes associated with the MC signature by Dywer et al. [18]. Gene expression of FLMC and FSMC normalized against BMMC. Upregulated genes are shown in red and downregulated genes in blue. $(n=3, \mathrm{FDR} \leq 0.01$, abslog $\left.F_{c}>2\right)$.

\subsection{Consequences of IgE and Antigen Mediated Crosslinking of FceRI in the MC Types Derived from Different Tissues}

One important pathway to activate MC is crosslinking the FceRI by IgE-antigen complexes, which leads to degranulation of MC [33]. We first looked at transcriptional differences in FceRI signaling in the MC from the three tissue types. For this we performed RNA sequencing from unstimulated MC and analyzed differential gene expression of genes involved in FceRI signaling, based on the pre-defined KEGG gene list (04664). As outlined above, we again normalized the expression levels of the genes of FLMC and FSMC against those of BMMC. Data are presented as a heatmap showing that, especially for genes related to the PI3K/Akt and MAPK signaling pathway, a log fold change of +3 in FSMC compared to BMMC was detected (Figure 4A). The transcriptional difference in genes involved in PI3K signaling in the BMMC, FLMC and FSMC, even in the absence of specific stimulation, supported our hypothesis that FSMC more closely resemble fully developed MC, as elevated PI3K activity drives MC maturation, while reduced PI3K activity modulates the maturation of in vitro MC towards a more myeloid-like cell type [34].

IgE-dependent activation of MC via FceRI crosslinking activates the downstream phospholipase $C-\gamma 1$ cascade. The activation of protein kinase $C$ releases calcium $\left(\mathrm{Ca}^{2+}\right)$ from intracellular stores, followed by an influx of $\mathrm{Ca}^{2+}$ from the extracellular space through calcium channels. $\mathrm{Ca}^{2+}$ influx is indispensable for $\mathrm{MC}$ activation and degranulation and critically depends on the membrane potential $[35,36]$. This downstream activation of the IP3 cascade is essential for granulogenesis and the release of preformed mediators [37].

MC were loaded with $2 \mu \mathrm{M}$ fura-2AM for 20 min at $37^{\circ} \mathrm{C}$ and intracellular $\mathrm{Ca}^{2+}$ was measured before and following the addition of DNP-HSA $(50 \mathrm{ng} / \mathrm{mL})$ to IgE-sensitized MC in the absence or presence of extracellular $\mathrm{Ca}^{2}$. All three $\mathrm{MC}$ types showed unequivocal FceRI-mediated $\mathrm{Ca}^{2+}$ influx (Figure $4 \mathrm{~B}$ ) and comparably sustained activation of the potassium channel SK4 essential for IgE-dependent MC degranulation [38] as demonstrated by patch-clamp analysis (Figure $4 \mathrm{C}$ ). Consistent with our phenotype analyses and culture selection based on MC FceRI expression, these data show that IgE-antigen complexes can activate all three MC populations.

Therefore, in the next step, we investigated mediators released in response to activation. Degranulation of MC was induced either by FceRI crosslinking or by PMA/ionomycin of $1 \times 10^{6}$ cells from each MC type in $1 \mathrm{~mL}$ volume. After $30 \mathrm{~min}$, we collected the supernatants and measured histamine concentration by ELISA. As shown in Figure 4D, histamine release of FSMC was significantly higher compared to that of FLMC and BMMC. Interestingly, measuring histamine in the supernatant following stimulation with PMA/ionomycin, bypassing IgE-antigen-mediated FceRI crosslinking, showed a significantly higher release of histamine from FSMC compared to BMMC, but also FLMC released large amounts (Figure 4D). The significant difference in histamine release is in line with the higher expression of $H d c$ and Tpsb2 in FSMC and it corresponds to the higher granule content shown by electron microscopy for FSMC compared to BMMC and FLMC. The determination of $\beta-$ hexosaminidase, another enzyme stored in MC granules and released upon degranulation, further confirmed our findings with fetal tissue-derived MC releasing higher concentrations of $\beta$-hexosaminidase (Figure $4 \mathrm{E}$ ). Taken together, the higher granule content, the 
stronger response upon FceRI signaling and the significantly higher release of histamine and B-hexosaminidase from FSMC indicate a difference in MC development dependent on the tissue of origin.

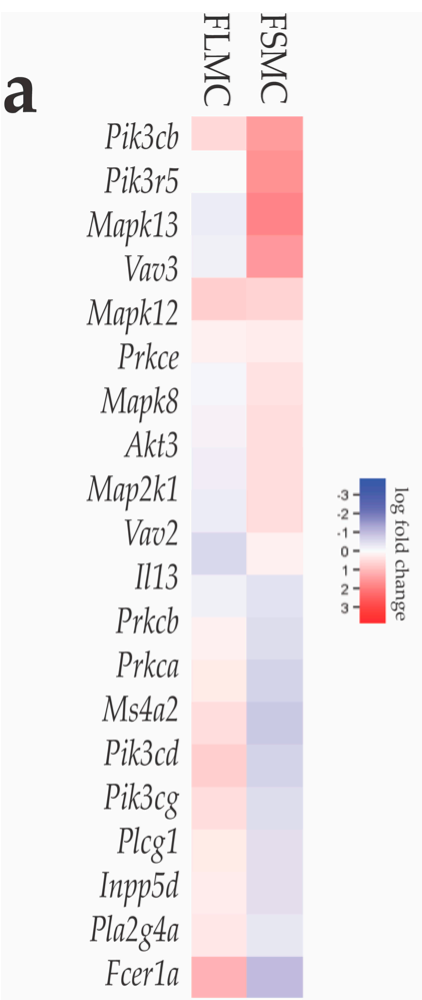

d

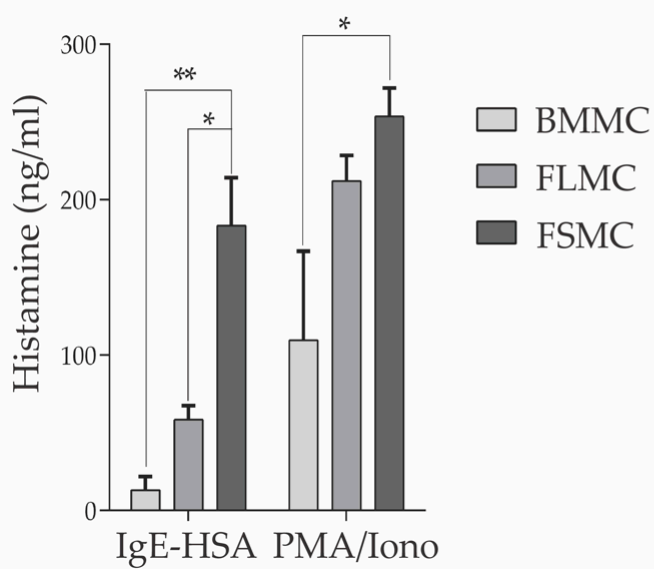

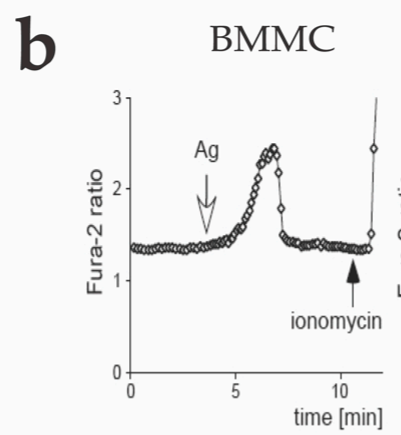
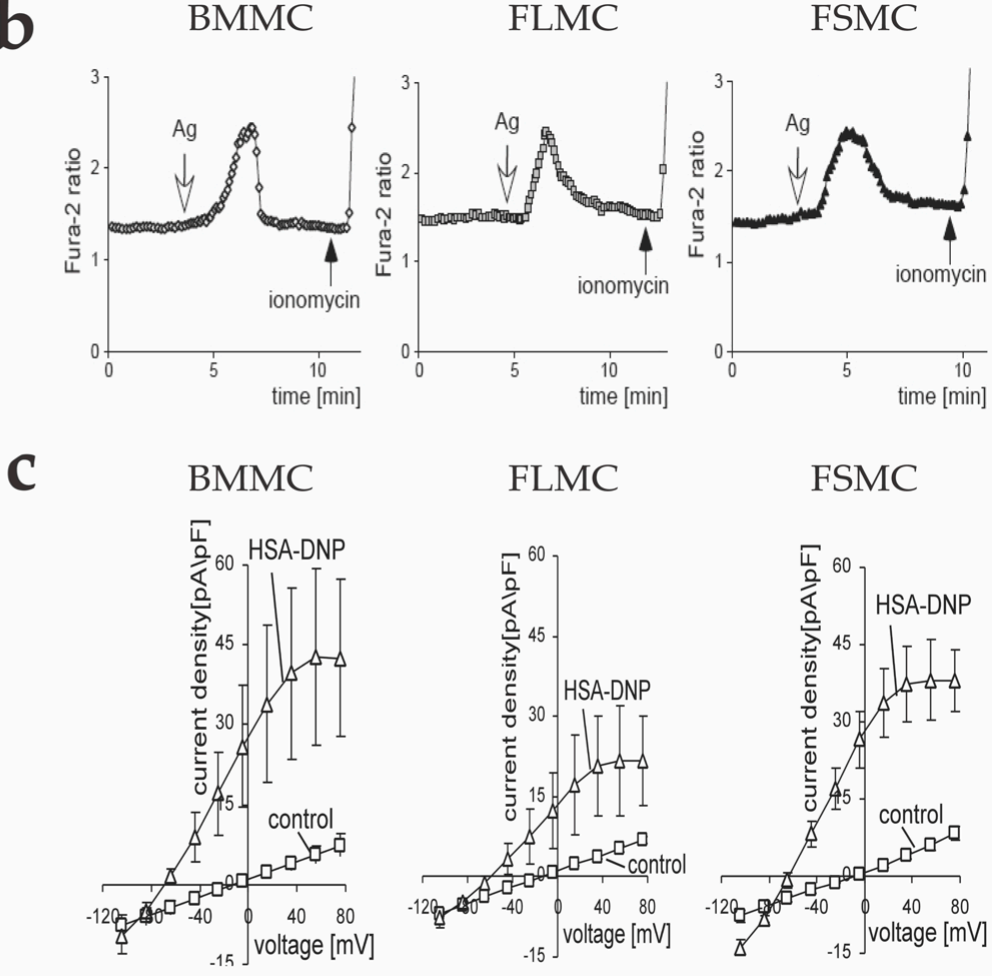

FSMC

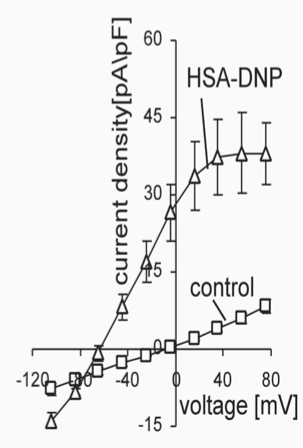

\section{e}

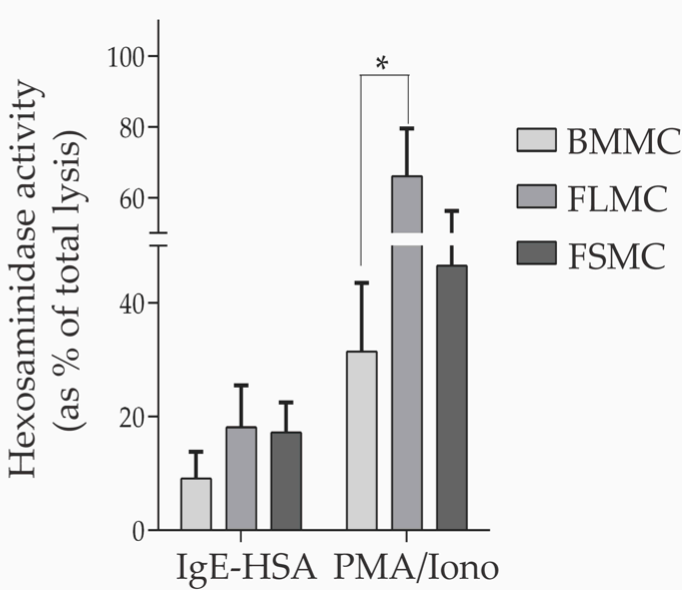

Figure 4. MC response to IgE stimulation. (a) Heatmap of differentially expressed genes relative to BMMC $($ FDR $>1$, abs $\log F C>1.5 \times)$. Gene list based on the FC_Epsilon_RI_Signaling gene set from KEGG. (b) MC were incubated over night with IgE anti-DNP. Prior to stimulation, cells were loaded with fluorescent Fura-2. Calcium influx was triggered by DNP-HSA. (c) Comparable sustained activation of the $\mathrm{K}$-channel SK4 as shown by patch clamp analysis. (d) Histamine levels detected in supernatant after PMA/ionomycin or IgE-HSA stimulation for $24 \mathrm{~h}$ using an enzyme-linked immunosorbent assay $\left(n=4\right.$, mean with SEM), $\left.{ }^{*} p>0.05^{* *} p>0.01\right)$. (e) MC were stimulated with PMA/ionomycin or IgE-DNP for $30 \mathrm{~min}$. Hexosaminidase activity was calculated as percent released relative to total cell lysis. ( $n=4$, mean with SEM), ${ }^{*} p>0.05$. 


\subsection{Toll-like Receptor Expression and Activation of In Vitro Generated MC of Different Tissue Origin}

In accordance with their role as innate sentinels, MC can also be activated through pathogen recognition receptors (PRR), including Toll like receptors (TLR) [39-41]. Thus, we first analyzed TLR expression by performing RT-PCR of unstimulated BMMC, FLMC and FSMC. Expression levels of the different TLRs relative to housekeeping gene $\beta$-actin were similar between the MC types for TLR3, TLR6, TLR7 and TLR9. Consistent with previous publications [42], no TLR5 expression could be detected (data not shown). Expression of TLR1, TLR2, and TLR4 was seen in all three MC types, but it was lower in FLMC (Figure 5A).

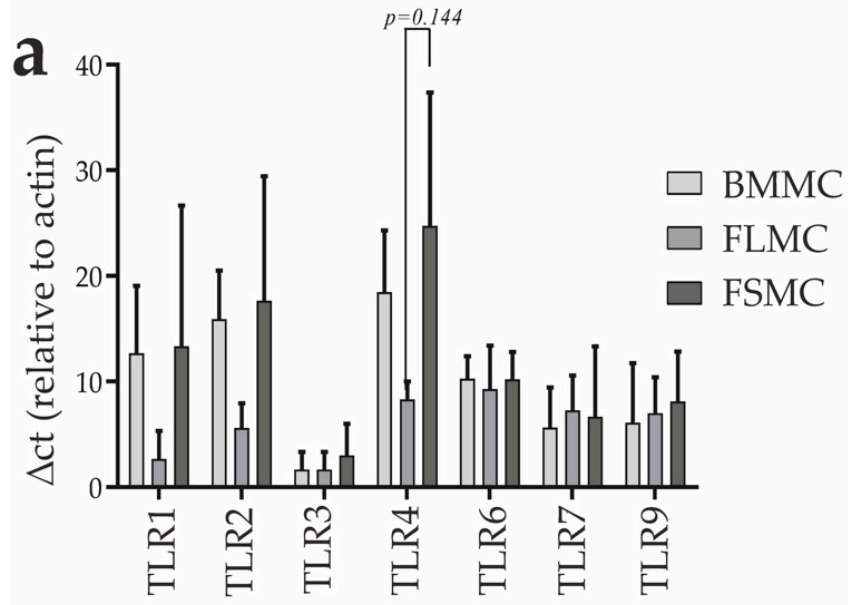

b
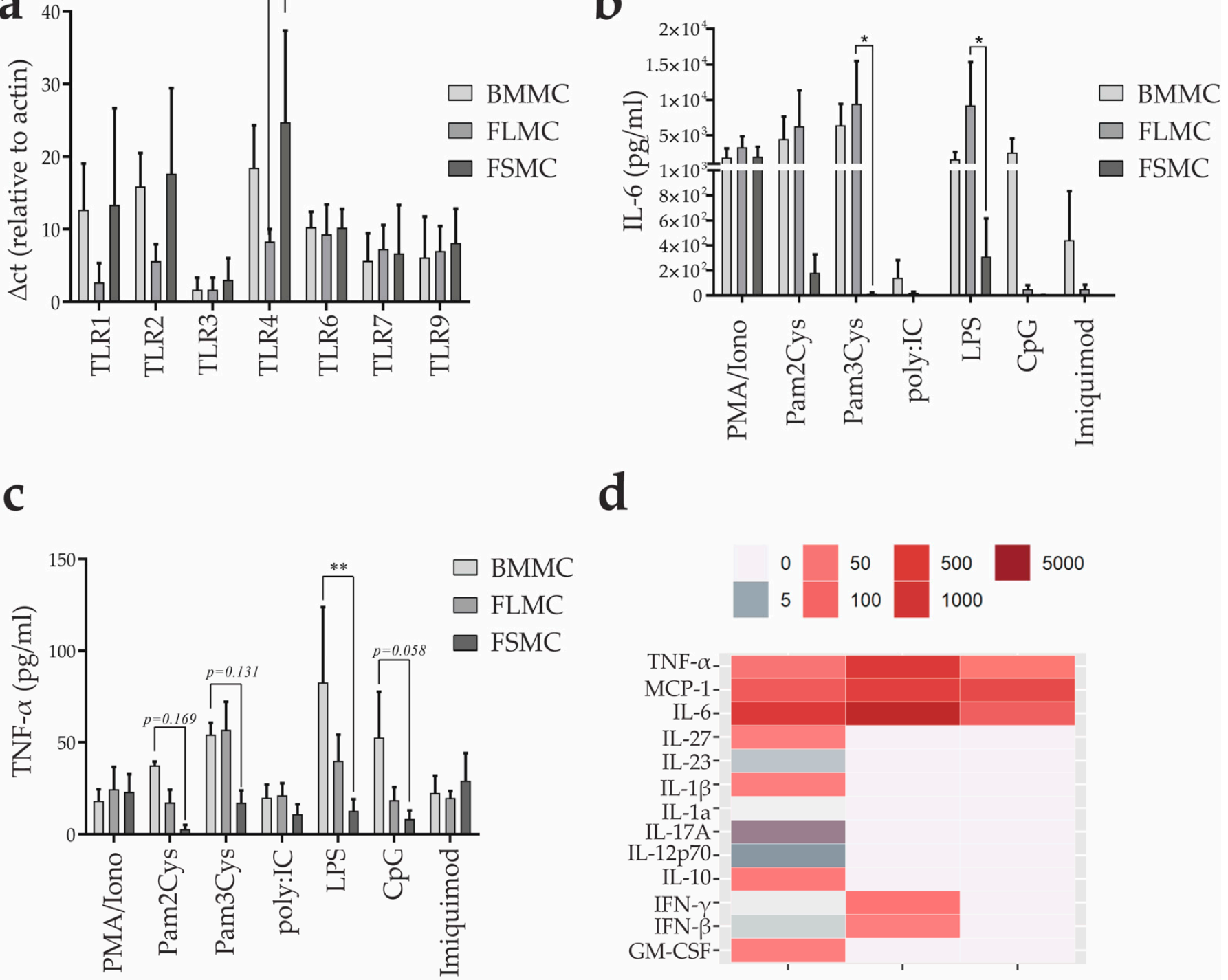

d

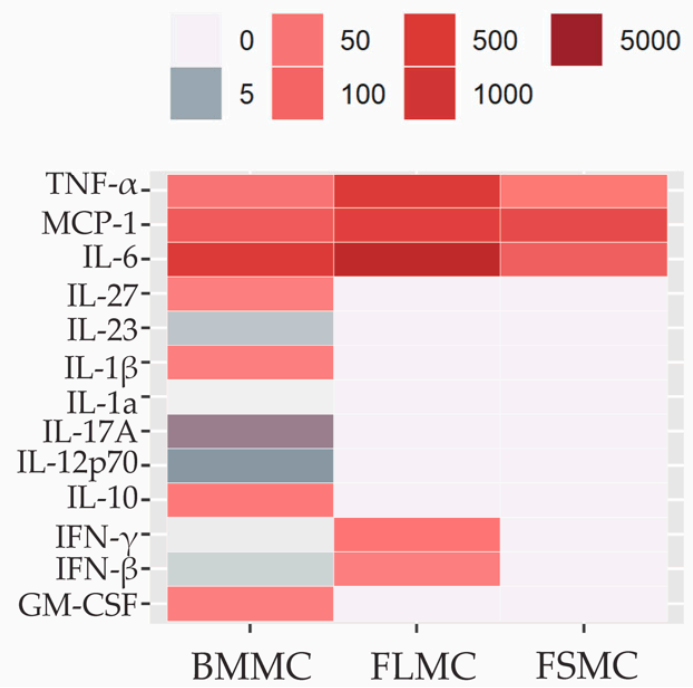

Figure 5. MC response towards TLR stimulation. (a) Toll-like receptor mRNA expression levels of MC analyzed by quantitative real-time PCR. $\Delta$ ct relative to housekeeping gene HPRT ( $n=3$, mean with SEM). (b,c) MC were stimulated with various TLR-agonists for $24 \mathrm{~h}$. Concentration of secreted (b) IL-6 and (c) TNF-a were measured in the supernatant via enzyme-linked immunosorbent assay ( $n=3$, mean with SEM). (d) MC were stimulated with LPS for $24 \mathrm{~h}$. Cytokines in the supernatant were analyzed using an enzyme-linked immunosorbent assay. Concentrations are given in $\mathrm{pg} / \mathrm{mL}$. Color gradient is depicted from $0-5000 \mathrm{pg} / \mathrm{mL} .{ }^{*} p>0.05,{ }^{* *} p>0.01$. 
Next, $1 \times 10^{6}$ cells of the three MC types were stimulated with Pam2Cys (TLR2/6), Pam3Cys (TLR1/2), poly:IC (TLR3), LPS (TLR4), Imiquimod (TLR7) or CpG OD 1668 (TLR9) for $24 \mathrm{~h}$ and concentrations of IL-6, known to be produced by MC upon activation, were measured in the supernatants. Interestingly and in contrast to the histamine release upon antigen-IgE activation, FSMC secreted the lowest amounts of IL-6 into the supernatant, while BMMC and FLMC showed higher levels of IL-6 production also compared to positive control stimulation by PMA/ionomycin. IL-6 upon TLR7 and TLR9 activation could only be measured in BMMC (Figure 5B). Regarding TNF- $\alpha$ production, TLR activation resulted in lower production in FSMC compared to BMMC and FLMC, especially in response to stimulation with Pam3Cys, LPS, and CpG (Figure 5C). Signaling of TLR4, the receptor for lipopolysaccharides (LPS) of Gram-negative bacteria, has been thoroughly investigated in MC and leads to NF-kB-dependent production of pro-inflammatory cytokines such as TNF- $\alpha$ and IL-6 [12,43]. The heatmap concentrations of inflammatory cytokines in the supernatant of BMMC, FLMC and FSMC upon stimulation with LPS for $24 \mathrm{~h}$ revealed a broad secretion of inflammatory cytokines from LPS-stimulated BMMC, with fewer cytokines being secreted by FLMC and FSMC, the latter only secreting TNF- $\alpha$, MCP-1, and IL-6 (Figure 5D). FSMC are less responsive to TLR activation regarding cytokine production compared to FLMC and BMMC, the latter showing highest levels of TNF- $\alpha$ production upon LPS and CpG activation but again lowest release of histamine upon activation via FceRI.

\section{Discussion}

MC biology and function have been fascinating many researchers over the years due to their multifaceted role in health and disease. Due to their plasticity, MC can act as direct effector cells or recruit innate and adaptive immune cells to modulate the immune response. Research focusing on $\mathrm{MC}$ has shown their essential role in allergy, autoimmune inflammation, and cancer $[12,44,45]$. In a recent paper, we were able to show an antitumorigenic effect of $\mathrm{MC}$ in the context of melanoma. Through activation of MC via TLR4, MC secrete CXCl10, which recruits tumor-specific T cells for effective antitumor responses [43]. Consequently, investigations on the role of MC steadily increase, involving both in vitro and in vivo analyses. As it is difficult to obtain primary MC in large numbers, it is well accepted to work with MC generated in vitro. In murine studies, classically bone marrow cells are used as input cells for these cultures, giving rise to large numbers of $\mathrm{MC}$ displaying many features of bona fide MC. However, these MC can only serve as models for mature tissue-type $\mathrm{MC}$ based on some shortcomings [46]. As alternative surrogates for MC, fetal-liver (FL) and fetal-skin (FS) derived MC have been described for in vitro studies. As early as 1983, mast-cell progenitors were identified in fetal tissue, developing in the yolk sac from gestation day 9.5 on, then forming MC progenitors in fetal livers and skin [47]. Gentek et al. applied single cell sequencing methods to decipher the fate mapping of MCs and confirmed that $\mathrm{MC}$ progenitors are found in fetal tissue and that in fact the majority of $\mathrm{MC}$ do not originate from bone marrow [3]. In light of this, we established a side-by-side culture of BMMC, FSMC and FLMC in this present study and performed comparative studies on functionality, proliferation capacity and mediator content as well as reactivity to IgE-crosslinking of the FceRI receptor and TLR ligands.

Several culture conditions under which BMMC are generated are being used in different labs, with varying FCS concentrations and with or without SCF in the medium $[29,48,49]$. We generated MC from adult bone marrow, fetal liver and fetal skin, and cultured these cells in medium containing SCF and IL-3 from conditioned medium. Even if the composition is not defined in detail, the use of conditioned media is generally accepted and widely used and therefore also used by us for our analyses. Our data show that the absence of SCF from MC culture conditions causes a reduction of FceRI and an increased MFI of CD117, indicating a shift from MC to basophils. This effect is visible as early as $12 \mathrm{~h}$ after deprivation of SCF. This finding is supported by Ohnmacht et al., who have shown the importance of IL-3 and SCF in the culture of MC from bone marrow progenitors, as lack of 
SCF favoured the generation of basophils also in their setting [50]. The highest yield of MC can be generated from $\mathrm{BMMC}$, and especially the high proliferation rate allows for the vast cultivation of large numbers of BMMC. However, with both FSMC and FLMC we were able to generate yields of $1 \times 10^{7}-5 \times 10^{7}$ cells/embryo, which, although the proliferation rates are low due to the higher degree of maturation, are still a sufficient quantity for repetitive in vitro experiments, making them a valuable tool for research.

Classically, MC have been characterized based on granule content and proteases they produce [51]. Our studies revealed that all three tissues, bone marrow, fetal liver, and fetal skin, give rise to $\mathrm{MC}$ as seen in our side-by-side cultures. However, histological staining and morphological properties indicate that FSMC are closest to tissue-derived mature CTMC whereas BMMC represent MC that are least developed/matured. Aside from the common surface markers FceRI and CD117, mature MC express the ST2 receptor constitutively [28]. In our study we were able to show the constitutive surface expression of ST2 on MC from cultures from all three tissues and that MC-specific responses to ST2 activation by IL-33 were strong in BMMC and FSMC and less pronounced in FLMC. Thus, determining ST2 expression adds to the phenotypic and functional characterization of $\mathrm{MC}$ generated in vitro.

IgE-dependent activation of tissue resident $\mathrm{MC}$ is the dominant pathway underlying immediate type allergic reactions [52]. MC can also be activated in vitro by crosslinking the FceRI by IgE-antigen complexes, which leads to degranulation of MC. We performed functional analyses of IgE-crosslinking of the FceRI receptor by measuring the intracellular $\mathrm{Ca}^{2+}$ before and following addition of DNP-HSA to IgE-sensitized MC in the absence or presence of extracellular $\mathrm{Ca}^{2}$. This revealed for all three $\mathrm{MC}$ types unequivocal immediate $\mathrm{Ca}^{2+}$ influx and identical sustained activation as detected by patch-clamp experiments for the K-channel SK4. However, significantly higher release of histamine and B-hexosaminidase from FSMC was observed upon IgE-crosslinking of the FceRI receptor. This is in line with our transcriptome data, which showed a higher log fold expression of $H d c$, the gene for histidine decarboxylase, and Tpsb2, the gene encoding for MC-tryptase in steady-state FSMC compared to BMMC. Together with the higher granule content observed in FSMC compared to BMMC, this indicates a difference in $\mathrm{MC}$ development or maturation dependent on the tissue of cell origin. Fetal-tissue-derived MC compared to BMMC showed a phenotype and reactions more closely resembling mature in vivo MC with FSMC being the most developed.

Data generated with murine $\mathrm{MC}$ are often used for translational aspects, however murine MC are different from their human counterparts, as the relative expression of IL- 6 in resting murine BMMC was greater in comparison to the human cord-blood derived MC [53]. Upon stimulation of MC from all three tissue types with TLR-agonists, we found that BMMC and FLMC release the highest concentrations of IL-6 upon stimulation with Pam3Cys (TLR1/2), Pam2Cys (TLR2/6) and LPS (TLR4). Interestingly and in contrast to the histamine release upon antigen-IgE activation, FSMC secreted the lowest amounts of IL-6 into the supernatant compared to positive control stimulation by PMA/ionomycin. In recent years, research on the role of MC in health and disease has focused on the mas-coupled receptor Mrgprx2. In our transcriptome analysis, we found a higher fold change of mrgprb2 (the mouse ortholog to mrgprx2) in both fetal-derived MC, making them a valuable tool for investigating the role of MC in skin-related diseases such as atopic dermatitis, allergic contact dermatitis and urticaria [54]. We further found a decreased fold change in s100a8 and s100a9 in fetal-skin derived MC. S100A8/A9 is an endogenous ligand of Toll-like receptor 4 (TLR4) and is implicated in the pathogenesis of inflammatory diseases. It was found that $\mathrm{S} 100 \mathrm{a} 8$ reduces $\mathrm{MC}$ degranulation and thereby the production of the cytokines IL-6 and IL-4 in response to IgE-crosslinking in vitro [55]. The reduction in the gene expression of s100a8 in FSMC compared to BMMC might explain the increased responsiveness towards crosslinking of the FceRI receptor by IgE-antigen complexes and the increased release of histamine and hexosaminidase, as shown in Figure 4. The main characteristics of MCs studied in this paper compared to CTMC are elaborated on in 
Table 2. Most of the experiments represented in this study were conducted using biological triplicates, to eliminate any batch-effects that might occur. The methods applied and presented in this study are continuously being applied in our research as the basis to ensure full maturation of in vitro generated $\mathrm{MC}$, thereby repeatedly confirming our findings.

Table 2. Characteristic profile of MC surrogates.

\begin{tabular}{|c|c|c|c|c|}
\hline Title 1 & BMMC & FLMC & FSMC & СТМC \\
\hline Alcian blue/safranin staining & Blue & Blue/Red & Red & red \\
\hline Toluidine staining & violet & Violet & Violet & violet \\
\hline Granules & + & ++ & +++ & +++ \\
\hline Histamine content & + & ++ & +++ & +++ \\
\hline Proteases & Mcpt4,5,6,7,9 Сpa3 & Mcpt4,5,6,7,9 Сpa3 & Mcpt4,5,6,7,9 Сра3 & Mcpt4,5,6,7,9 Сpa3 \\
\hline Degranulation by $\operatorname{IgE}$ & $\begin{array}{ll}1 & +++\end{array}$ & +++ & $\begin{array}{ll}1 & +++\end{array}$ & $\begin{array}{ll}1 & +++\end{array}$ \\
\hline TLR expression & TLR1,2,3,4,6,7,8 & TLR1,2,3,4,6,7,8 & TLR1,2,3,4,6,7,8 & TLR1,2,3,4,6,7,8,9 \\
\hline \multicolumn{5}{|l|}{ Phenotype } \\
\hline $\mathrm{CD} 45$ & + & + & + & + \\
\hline CD117 & + & + & + & + \\
\hline FceRI & + & + & + & + \\
\hline ST2 expression & ++ & + & ++ & ++ \\
\hline Cytokine secretion upon LPS stimulation & +++ & ++ & + & +++ \\
\hline Cytokine secretion upon IL-33 stimulation & +++ & + & +++ & +++ \\
\hline
\end{tabular}

\section{Conclusions}

The maturation of MC takes place through an accurate and on-time gene expression program, regulated by the tissue-specific and non-specific transcription factors. Therefore, MC heterogeneity is a result of the microenvironment, which educates the cells and consequently, the effector functions of MCs are different depending on the tissue in which the cell mature and differentiate $[9,56,57]$. Our studies showed that there are differences between MC generated in vitro from different tissues that need to be addressed, especially when MC immune functions are studied. Our study indicates that there is already an imprinting of the precursor cells for $\mathrm{MC}$ in fetal tissues that remains effective even during in vitro cultivation. Thus, the tissue of origin imprints MC precursor cells so that these cells, despite identical culture conditions and consecutive equal surface expression of CD117 and FceRI, acquire distinct phenotypes and signatures. Under basal conditions, even within the same tissue, MC populations are phenotypically different and form further specific subpopulations [58]. With this study we shed light on the heterogeneity of MC used for in vitro analysis and show that fetal-derived $\mathrm{MC}$ may be a more appropriate surrogate for some in vitro studies, as these cells show a higher degree of differentiation and maturity and thus resemble connective tissue MC more closely. Of course, research with fetal tissue needs to adhere to local regulations, however organ retrieval is generally accepted.

Supplementary Materials: The following supporting information can be downloaded at: https: / / www.mdpi.com/article/10.3390/cells11060928/s1, Figure S1: In vitro Generation of Mast Cells; Figure S2: Characterization of MC; Table S1: List of Primers.

Author Contributions: T.B. and S.K. designed and conceptualized the study and wrote the paper. C.I. and S.K. performed, interpreted, and analyzed experiments and wrote the paper. N.H. (Nils Hoffard) and T.S. helped with the bioinformatic data analysis. M.A.-K., M.H., M.K., F.W., E.S., N.H. (Nicole Heise), B.F., M.S. and F.L. offered methodological support. All authors have read and agreed to the published version of the manuscript.

Funding: This research was funded by the Deutsche Forschungsgemeinschaft (DFG) Project-ID 360372040 -SFB 1335, SFB824 project B10, SFB1371 project P06 and RTG2668 project A2 and project B3.

Institutional Review Board Statement: Not applicable.

Informed Consent Statement: Not applicable.

Data Availability Statement: The data sets generated during the current study are available from the corresponding authors on reasonable request. 
Acknowledgments: We gratefully acknowledge Ulrike Schmidt, Stefanie Müller, Sabrina Engel and Desiree Argiriu for excellent technical assistance. We thank Rupert Öllinger and Thomas Engleitner for RNA sequencing and data analysis.

Conflicts of Interest: The authors declare no conflict of interest.

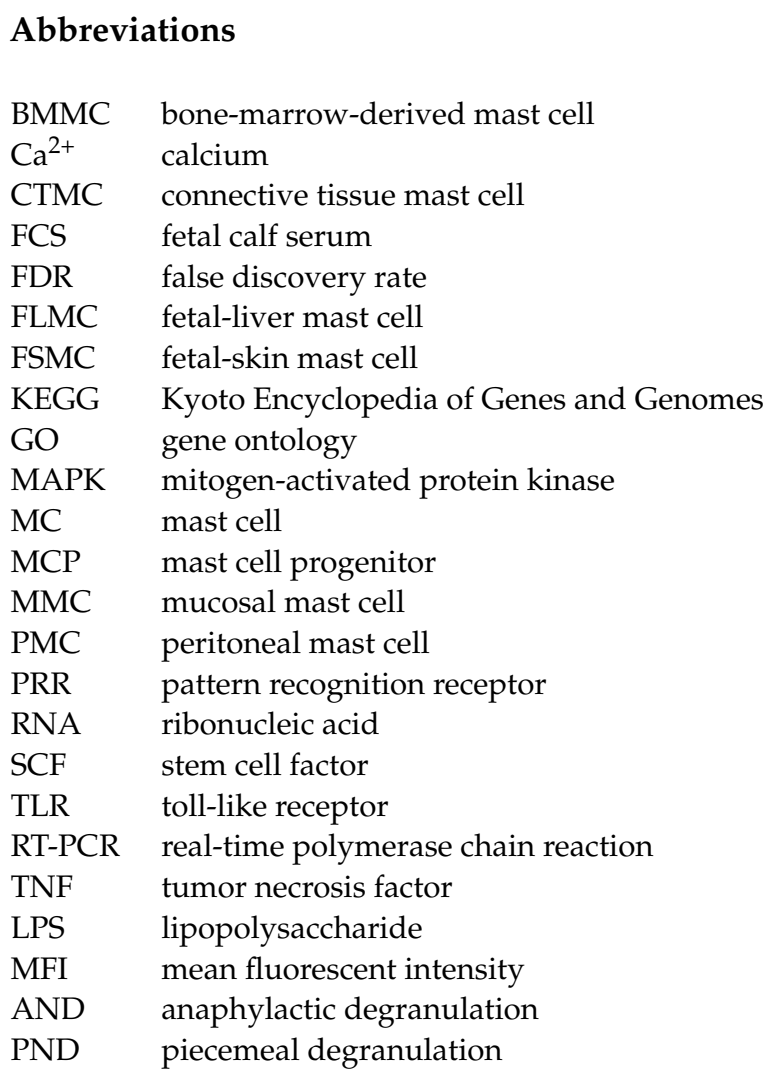

\section{References}

1. Elieh Ali Komi, D.; Wöhrl, S.; Bielory, L. Mast Cell Biology at Molecular Level: A Comprehensive Review. Clin. Rev. Allergy Immunol. 2020, 58, 342-365. [CrossRef] [PubMed]

2. Dahlin, J.S.; Hamey, F.K.; Pijuan-Sala, B.; Shepherd, M.; Lau, W.W.Y.; Nestorowa, S.; Weinreb, C.; Wolock, S.; Hannah, R.; Diamanti, E.; et al. A single-cell hematopoietic landscape resolves 8 lineage trajectories and defects in Kit mutant mice. Blood 2018, 131, e1-e11. [CrossRef] [PubMed]

3. Gentek, R.; Ghigo, C.; Hoeffel, G.; Bulle, M.J.; Msallam, R.; Gautier, G.; Launay, P.; Chen, J.; Ginhoux, F.; Bajénoff, M. Hemogenic Endothelial Fate Mapping Reveals Dual Developmental Origin of Mast Cells. Immunity 2018, 48, 1160-1171.e5. [CrossRef] [PubMed]

4. Grootens, J.; Ungerstedt, J.S.; Nilsson, G.; Dahlin, J.S. Deciphering the differentiation trajectory from hematopoietic stem cells to mast cells. Blood Adv. 2018, 2, 2273-2281. [CrossRef]

5. Tusi, B.K.; Wolock, S.L.; Weinreb, C.; Hwang, Y.; Hidalgo, D.; Zilionis, R.; Waisman, A.; Huh, J.R.; Klein, A.M.; Socolovsky, M. Population snapshots predict early haematopoietic and erythroid hierarchies. Nature 2018, 555, 54-60. [CrossRef]

6. Hallgren, J.; Gurish, M.F. Mast cell progenitor trafficking and maturation. Adv. Exp. Med. Biol. 2011, 716, 14-28. [CrossRef]

7. Collington, S.J.; Hallgren, J.; Pease, J.E.; Jones, T.G.; Rollins, B.J.; Westwick, J.; Austen, K.F.; Williams, T.J.; Gurish, M.F.; Weller, C.L. The Role of the CCL2/CCR2 Axis in Mouse Mast Cell Migration In Vitro and In Vivo. J. Immunol. 2010, 184, 6114-6123. [CrossRef]

8. Galli, S.J.; Tsai, M. IgE and mast cells in allergic disease. Nat. Med. 2012, 18, 693-704. [CrossRef]

9. Frossi, B.; Mion, F.; Sibilano, R.; Danelli, L.; Pucillo, C.E.M. Is it time for a new classification of mast cells? What do we know about mast cell heterogeneity? Immunol. Rev. 2018, 282, 35-46. [CrossRef]

10. Biedermann, T.; Kneilling, M.; Mailhammer, R.; Maier, K.; Sander, C.A.; Kollias, G.; Kunkel, S.L.; Hültner, L.; Röcken, M. Mast Cells Control Neutrophil Recruitment during T Cell-Mediated Delayed-Type Hypersensitivity Reactions through Tumor Necrosis Factor and Macrophage Inflammatory Protein 2. J. Exp. Med. 2000, 192, 1441-1452. [CrossRef]

11. Maurer, M.; Köberle, M.; Metz, M.; Biedermann, T. Mast cells: Promoters of health and modulators of disease. J. Allergy Clin. Immunol. 2019, 144, S1-S3. [CrossRef] [PubMed]

12. Dudeck, A.; Köberle, M.; Goldmann, O.; Meyer, N.; Dudeck, J.; Lemmens, S.; Rohde, M.; Roldán, N.G.; Dietze-Schwonberg, K.; Orinska, Z.; et al. Mast cells as protectors of health. J. Allergy Clin. Immunol. 2019, 144, S4-S18. [CrossRef] [PubMed] 
13. Marichal, T.; Tsai, M.; Galli, S.J. Mast Cells: Potential Positive and Negative Roles in Tumor Biology. Cancer Immunol. Res. 2013, 1, 269-279. [CrossRef]

14. Varricchi, G.; Galdiero, M.R.; Loffredo, S.; Marone, G.; Iannone, R.; Marone, G.; Granata, F. Are Mast Cells MASTers in Cancer? Front. Immunol. 2017, 8, 424. [CrossRef]

15. Dahlin, J.S.; Maurer, M.; Metcalfe, D.D.; Pejler, G.; Sagi-Eisenberg, R.; Nilsson, G. The ingenious mast cell: Contemporary insights into mast cell behavior and function. Allergy 2021, 77, 83-99. [CrossRef]

16. Kovarova, M. Isolation and Characterization of Mast Cells in Mouse Models of Allergic Diseases. In Mouse Models of Allergic Disease: Methods and Protocols; Allen, I.C., Ed.; Humana Press: Totowa, NJ, USA, 2013; pp. 109-119.

17. Yu, T.; He, Z.; Yang, M.; Song, J.; Ma, C.; Ma, S.; Feng, J.; Liu, B.; Wang, X.; Wei, Z.; et al. The development of methods for primary mast cells in vitro and ex vivo: An historical review. Exp Cell Res. 2018, 369, 179-186. [CrossRef]

18. Dwyer, D.F.; Barrett, N.A.; Austen, K.F. Expression profiling of constitutive mast cells reveals a unique identity within the immune system. Nat. Immunol. 2016, 17, 878-887. [CrossRef]

19. Li, Z.; Liu, S.; Xu, J.; Zhang, X.; Han, D.; Liu, J.; Xia, M.; Yi, L.; Shen, Q.; Xu, S.; et al. Adult Connective Tissue-Resident Mast Cells Originate from Late Erythro-Myeloid Progenitors. Immunity 2018, 49, 640-653.e5. [CrossRef]

20. Matsue, H.; Kambe, N.; Shimada, S. Murine fetal skin-derived cultured mast cells: A useful tool for discovering functions of skin mast cells. J. Investig. Dermatol. 2009, 129, 1120-1125. [CrossRef]

21. Yamada, N.; Matsushima, H.; Tagaya, Y.; Shimada, S.; Katz, S.I. Generation of a large number of connective tissue type mast cells by culture of murine fetal skin cells. J. Investig. Dermatol. 2003, 121, 1425-1432. [CrossRef]

22. Ribatti, D. The Staining of Mast Cells: A Historical Overview. Int. Arch. Allergy Immunol. 2018, 176, 55-60. [CrossRef] [PubMed]

23. Duelli, A.; Rönnberg, E.; Waern, I.; Ringvall, M.; Kolset, S.O.; Pejler, G. Mast cell differentiation and activation is closely linked to expression of genes coding for the serglycin proteoglycan core protein and a distinct set of chondroitin sulfate and heparin sulfotransferases. J. Immunol. 2009, 183, 7073-7083. [CrossRef] [PubMed]

24. Grigorev, I.P.; Korzhevskii, D.E. Modern Imaging Technologies of Mast Cells for Biology and Medicine (Review). Sovrem. Tekhnol. Med. 2021, 13, 93-107. [CrossRef] [PubMed]

25. Feyerabend, T.B.; Hausser, H.; Tietz, A.; Blum, C.; Hellman, L.; Straus, A.H.; Takahashi, H.K.; Morgan, E.S.; Dvorak, A.M.; Fehling, H.J.; et al. Loss of histochemical identity in mast cells lacking carboxypeptidase A. Mol. Cell Biol. 2005, 25, 6199-6210. [CrossRef] [PubMed]

26. Russ, H.A.; Bar, Y.; Ravassard, P.; Efrat, S. In Vitro Proliferation of Cells Derived From Adult Human $\beta$-Cells Revealed By Cell-Lineage Tracing. Diabetes 2008, 57, 1575-1583. [CrossRef] [PubMed]

27. Guo, Y.; Pu, W.T. Cardiomyocyte Maturation. Circ. Res. 2020, 126, 1086-1106. [CrossRef]

28. Cayrol, C.; Girard, J.-P. Interleukin-33 (IL-33): A nuclear cytokine from the IL-1 family. Immunol. Rev. 2018, 281, 154-168. [CrossRef]

29. Eissmann, M.F.; Dijkstra, C.; Jarnicki, A.; Phesse, T.; Brunnberg, J.; Poh, A.R.; Etemadi, N.; Tsantikos, E.; Thiem, S.; Huntington, N.D.; et al. IL-33-mediated mast cell activation promotes gastric cancer through macrophage mobilization. Nat. Commun. 2019, 10, 2735. [CrossRef]

30. Leyva-Castillo, J.M.; Das, M.; Artru, E.; Yoon, J.; Galand, C.; Geha, R.S. Mast cell-derived IL-13 downregulates IL-12 production by skin dendritic cells to inhibit the $\mathrm{T}(\mathrm{H}) 1$ cell response to cutaneous antigen exposure. J. Allergy Clin. Immunol. 2021, 147, 2305-2315.e3. [CrossRef]

31. Pejler, G.; Rönnberg, E.; Waern, I.; Wernersson, S. Mast cell proteases: Multifaceted regulators of inflammatory disease. Blood 2010, 115, 4981-4990. [CrossRef]

32. Payne, V.; Kam, P.C. Mast cell tryptase: A review of its physiology and clinical significance. Anaesthesia 2004, 59, 695-703. [CrossRef]

33. Shumilina, E.; Lam, R.S.; Wölbing, F.; Matzner, N.; Zemtsova, I.M.; Sobiesiak, M.; Mahmud, H.; Sausbier, U.; Biedermann, T.; Ruth, P.; et al. Blunted IgE-mediated activation of mast cells in mice lacking the $\mathrm{Ca}^{2+}$-activated $\mathrm{K}^{+}$channel $\mathrm{KCa}_{3.1}$. J. Immunol. 2008, 180, 8040-8047. [CrossRef] [PubMed]

34. Ma, P.; Mali, R.S.; Munugalavadla, V.; Krishnan, S.; Ramdas, B.; Sims, E.; Martin, H.; Ghosh, J.; Li, S.; Chan, R.J.; et al. The PI3K pathway drives the maturation of mast cells via microphthalmia transcription factor. Blood 2011, 118, 3459-3469. [CrossRef] [PubMed]

35. Krystel-Whittemore, M.; Dileepan, K.N.; Wood, J.G. Mast Cell: A Multi-Functional Master Cell. Front. Immunol. 2015, 6, 620. [CrossRef] [PubMed]

36. Vennekens, R.; Olausson, J.; Meissner, M.; Bloch, W.; Mathar, I.; Philipp, S.E.; Schmitz, F.; Weissgerber, P.; Nilius, B.; Flockerzi, $\mathrm{V}$; et al. Increased IgE-dependent mast cell activation and anaphylactic responses in mice lacking the calcium-activated nonselective cation channel TRPM4. Nat. Immunol. 2007, 8, 312-320. [CrossRef] [PubMed]

37. Froghi, S.; Grant, C.R.; Tandon, R.; Quaglia, A.; Davidson, B.; Fuller, B. New Insights on the Role of TRP Channels in Calcium Signalling and Immunomodulation: Review of Pathways and Implications for Clinical Practice. Clin. Rev. Allergy Immunol. 2021, 60, 271-292. [CrossRef] [PubMed]

38. Sobiesiak, M.; Shumilina, E.; Lam, R.S.; Wölbing, F.; Matzner, N.; Kaesler, S.; Zemtsova, I.M.; Lupescu, A.; Zahir, N.; Kuhl, D.; et al. Impaired Mast Cell Activation in Gene-Targeted Mice Lacking the Serum- and Glucocorticoid-Inducible Kinase SGK1. J. Immunol. 2009, 183, 4395-4402. [CrossRef] 
39. Agier, J.; Pastwińska, J.; Brzezińska-Błaszczyk, E. An overview of mast cell pattern recognition receptors. Inflamm. Res. 2018, 67, 737-746. [CrossRef]

40. Matsushima, H.; Yamada, N.; Matsue, H.; Shimada, S. TLR3-, TLR7-, and TLR9-mediated production of proinflammatory cytokines and chemokines from murine connective tissue type skin-derived mast cells but not from bone marrow-derived mast cells. J. Immunol. 2004, 173, 531-541. [CrossRef]

41. Supajatura, V.; Ushio, H.; Nakao, A.; Akira, S.; Okumura, K.; Ra, C.; Ogawa, H. Differential responses of mast cell Toll-like receptors 2 and 4 in allergy and innate immunity. J. Clin. Investig. 2002, 109, 1351-1359. [CrossRef]

42. Agier, J.; Żelechowska, P.; Kozłowska, E.; Brzezińska-Błaszczyk, E. Expression of surface and intracellular Toll-like receptors by mature mast cells. Cent. Eur. J. Immunol. 2016, 41, 333-338. [CrossRef] [PubMed]

43. Kaesler, S.; Wölbing, F.; Kempf, W.E.; Skabytska, Y.; Köberle, M.; Volz, T.; Sinnberg, T.; Amaral, T.; Möckel, S.; Yazdi, A.; et al. Targeting tumor-resident mast cells for effective anti-melanoma immune responses. JCI Insight 2019, 4, 125057. [CrossRef] [PubMed]

44. Kneilling, M.; Hültner, L.; Pichler, B.J.; Mailhammer, R.; Morawietz, L.; Solomon, S.; Eichner, M.; Sabatino, J.; Biedermann, T.; Krenn, V.; et al. Targeted mast cell silencing protects against joint destruction and angiogenesis in experimental arthritis in mice. Arthritis Rheum. 2007, 56, 1806-1816. [CrossRef] [PubMed]

45. Kneilling, M.; Mailhammer, R.; Hültner, L.; Schönberger, T.; Fuchs, K.; Schaller, M.; Bukala, D.; Massberg, S.; Sander, C.A.; Braumüller, H.; et al. Direct crosstalk between mast cell-TNF and TNFR1-expressing endothelia mediates local tissue inflammation. Blood 2009, 114, 1696-1706. [CrossRef] [PubMed]

46. Mrabet-Dahbi, S.; Metz, M.; Dudeck, A.; Zuberbier, T.; Maurer, M. Murine mast cells secrete a unique profile of cytokines and prostaglandins in response to distinct TLR2 ligands. Exp. Dermatol. 2009, 18, 437-444. [CrossRef]

47. Sonoda, T.; Kitamura, Y.; Haku, Y.; Hara, H.; Mori, K.J. Mast-cell precursors in various haematopoietic colonies of mice produced in vivo and in vitro. Br. J. Haematol. 1983, 53, 611-620. [CrossRef]

48. Meurer, S.K.; Neß, M.; Weiskirchen, S.; Kim, P.; Tag, C.G.; Kauffmann, M.; Huber, M.; Weiskirchen, R. Isolation of Mature (Peritoneum-Derived) Mast Cells and Immature (Bone Marrow-Derived) Mast Cell Precursors from Mice. PLoS ONE 2016, 11, e0158104. [CrossRef]

49. Swindle, E.J. Generation of Mast Cells from Murine Stem Cell Progenitors. Methods Mol. Biol. 2020, 2163, 85-89. [CrossRef] [PubMed]

50. Ohnmacht, C.; Voehringer, D. Basophil effector function and homeostasis during helminth infection. Blood 2009, 113, 2816-2825 [CrossRef]

51. Galli, S.J.; Tsai, M.; Marichal, T.; Tchougounova, E.; Reber, L.L.; Pejler, G. Approaches for analyzing the roles of mast cells and their proteases in vivo. Adv. Immunol. 2015, 126, 45-127. [CrossRef]

52. Tsai, M.; Grimbaldeston, M.A.; Yu, M.; Tam, S.-Y.; Galli, S.J. Using Mast Cell Knock-In Mice to Analyze the Roles of Mast Cells in Allergic Responses in vivo. Chem. Immunol. Allergy 2005, 87, 179-197. [CrossRef] [PubMed]

53. Nakajima, T. Marked increase in CC chemokine gene expression in both human and mouse mast cell transcriptomes following Fcepsilon receptor I cross-linking: An interspecies comparison. Blood 2002, 100, 3861-3868. [CrossRef] [PubMed]

54. Roy, S.; Chompunud Na Ayudhya, C.; Thapaliya, M.; Deepak, V.; Ali, H. Multifaceted MRGPRX2: New insight into the role of mast cells in health and disease. J. Allergy Clin. Immunol. 2021, 148, 293-308. [CrossRef] [PubMed]

55. Zhao, J.; Endoh, I.; Hsu, K.; Tedla, N.; Endoh, Y.; Geczy, C.L. S100A8 modulates mast cell function and suppresses eosinophil migration in acute asthma. Antioxid. Redox Signal. 2011, 14, 1589-1600. [CrossRef]

56. Gurish, M.F.; Austen, K.F. Developmental origin and functional specialization of mast cell subsets. Immunity 2012, 37, 25-33 [CrossRef]

57. Saito, H.; Matsumoto, K.; Okumura, S.; Kashiwakura, J.; Oboki, K.; Yokoi, H.; Kambe, N.; Ohta, K.; Okayama, Y. Gene expression profiling of human mast cell subtypes: An in silico study. Allergol. Int. 2006, 55, 173-179. [CrossRef]

58. Xing, W.; Austen, K.F.; Gurish, M.F.; Jones, T.G. Protease phenotype of constitutive connective tissue and of induced mucosal mast cells in mice is regulated by the tissue. Proc. Natl. Acad. Sci. USA 2011, 108, 14210-14215. [CrossRef] 